\title{
The missing asymmetry in the Polish house price cycle: an analysis of the behaviour of house prices in 17 major cities
}

\author{
Justyna Brzezicka ${ }^{1} \cdot J^{\prime}$ acek Łaszek $^{2} \cdot \mathrm{Krzysztof}$ Olszewski ${ }^{2} \cdot$ Radoslaw Wisniewski $^{3}$ (D)
}

Received: 7 October 2019 / Accepted: 7 May 2021 / Published online: 20 June 2021

(c) The Author(s) 2021

\begin{abstract}
This paper investigates the house price cycle in 17 major cities in Poland, analysing separately prices of newly constructed housing and prices in the existing stock. We apply the Andre, Gupta and Mwamba (2019) framework and test the deepness and steepness of the cycles. Deepness concerns the relative magnitude of peaks and downturns, while steepness determines, how fast peaks or downturns are reached. When at least one of those measures is not symmetric, there is asymmetry in the cycle. We apply the triples test and the entropy test and find little evidence for asymmetry, mostly only in small cities. This seems to be intriguing, because usually there are asymmetries, for example slow price increases end in sudden drops. The explanation for the smooth cycle in the Polish housing market are a still not satisfied demand for housing and continuously growing wages. Banks issued mortgages only to the more affluent people, which were able to pay back the mortgage. Additionally, two housing subsidy schemes helped to keep house prices stable, when the situation in the global economy worsened, which might have led to price drops.
\end{abstract}

Keywords Housing market $\cdot$ House price cycle $\cdot$ Asymmetry $\cdot$ Price fluctuations $\cdot$ Triples test $\cdot$ Entropy test $\cdot$ Deepness $\cdot$ Steepness

JEL Classifications E30 $\cdot$ R21

This article presents the opinions of its authors and not necessarily the official position of the Narodowy Bank Polski.

Radoslaw Wisniewski

r.wisniewski@vizja.pl

1 Institute of Geospatial Engineering and Real Estate, University of Warmia and Mazury, Olsztyn, Poland

2 Collegium of Business Administration, Poland and Narodowy Bank Polski, Economic Analysis Department, Warsaw School of Economics, Warsaw, Poland

3 University of Economics and Human Sciences, Warsaw, Poland 


\section{Introduction}

In this article we analyse the house price cycle in the 17 largest Polish cities during 2007-2018 to demonstrate how the market evolved and to determine why the Global Financial Crisis did not lead to a crisis on the Polish real estate market, but only induced a gradual decline in house prices. Most developed countries experienced a significant increase in prices before 2007 and a significant decrease thereafter, which, combined with the highly developed mortgage market, has led to problems in the financial and banking sectors. In many cases, the outstanding mortgage exceeded the value of the encumbered property. As a consequence, banks lost much of their mortgage collateral and had to match their balances with the reduced equity. Financial institutions operating on these markets and investing in mortgage debt recorded losses, which resulted in losses in the savings of households who invested in such instruments. The fact that debt exceeded the collateral value had also negative consequences for mortgage takers. They had to limit their expenses and pay off debts. The deleveraging process began, in which banks reduced their lending and households reduced their consumption. The above problems had a direct negative impact on global demand which resulted in an economic slowdown.

International studies show that house price cycles have a significant impact on financial stability and consequently on economic growth (European Central Bank, 2005; Jordá et al. 2014; Reinhart \& Rogoff, 2009). Leamer (2007, 2015) states that housing is the business cycle, which means that house purchases determine the evolution of economic growth in the near future. The reason why house prices are so important for economic growth and financial stability, which in consequence directly affects the well-being of the citizens, is that most house purchases in developed countries are financed with a mortgage. During an economic upswing, growing wages allow people to take bigger mortgages and to buy better, thus more expensive housing. Under a rigid supply in the short run, house prices grow. New housing units need to be constructed, which generates jobs in many fields. The construction sector needs to hire more workers who produce materials, transport them and construct housing. New housing requires also new furniture and other outfits, and the owners will ask for different kinds of services in the future. Also the banking sector expands as more bank clerks are needed to process the mortgage applications. During normal times, the growth in the housing market has a positive effect on the overall economy. Aoki et al. (2004) apply a general equilibrium model which draws on the financial accelerator model of Bernanke et al. (1999) to UK house prices and show that even small decreases of interest rates can lead to house price growth, but also to growth of consumption. Iacoviello and Neri (2010), who use a dynamic stochastic equilibrium model, show that there are nonnegligible positive spillover effect on consumption that stem from house price growth. The house price cycle is fuelled also by speculations and herding behaviour, as Herring and Wachter (1999) and Malpezzi and Wachter (2005) explain. However, once the economy starts to slow down, the unemployment rate increases and wages drop, people start to have problems to pay back the mortgage. Also fewer people decide to buy housing and in consequences house prices decline. In this case, the herding behaviour and disaster myopia start to accelerate the downturn (see Herring \& Wachter, 1999). The value of the mortgage collateral declines and more and more people have problems to pay back the mortgage. In such a situation banks record losses, and need to deleverage, which means that they have to curb lending (see Iacoviello, 2015). Households also begin deleveraging, as their assets become lower than their debt. This in turn slows down economic growth and leads to further house price declines. In the worst case this leads to a recession, as the one observed 
in the US, EU, and other developed countries during 2007-2010. ${ }^{1}$ Herring and Wachter (1999) state that many of the previously observed housing booms end in banking busts. Girouard et al. (2006) analysed house price booms in the OECD countries between 1970 and the mid-1990s and identified thirty-seven boom periods, of which only $35 \%$ did not result in a bust. In those cases, the increase in prices could be explained by favourable fundamental factors.

The cyclical nature of the housing market is its well-known and rather impossible to eliminate structural feature. The fundamental causes of cyclicality are usually a fluctuating demand, a rigid supply, speculations and a short-sighted financial system. However, the main problem are housing crises, which occur much less frequently, but have a severe impact on the economy. They are caused by the same factors that drive the cycles, but these impulses are stronger and usually we deal with the accumulation of many of them. The challenge is to understand when the house price cycle is "business as usual" and when there are signs of serious tensions building up which will lead to a housing crisis. The processes of financial market globalization, the related deregulation of housing markets and the loose monetary policy were the causes of several serious housing crises in the last decades. As a consequence, a rich literature emerged that described the related processes and proposed different systems to monitor the tensions. Usually these are systems based on econometric models or advanced indicator systems that monitor key entities and markets. Their early warning capabilities are quite good, but their primary weakness is that they are based on our past experiences, and history shows that the developments that lead to a crisis can be different each time they appear. The second weakness of advanced models is that they require access to a large amount of detailed data about the sector and, consequently, a large amount of time and labor. Therefore, a legitimate question arises whether it is possible to analyze the risks associated with the housing cycle or a potential crisis only on the basis of time series of housing prices.

We can assume based on past historical experiences that when the house price cycle is more symmetric, the growth and subsequent decline in the housing market are rather moderate. When house prices grow slowly and then also decline slowly, the adjustments in the housing sector will be moderate and should not generate any substantial risk to the performance of the overall economy. Contrary, if tensions have built up over a long time and demand drops suddenly, the following decline in prices can lead to an economic and financial crisis can emerge. Therefore, it is crucial for housing policy, economic policy and also monetary policy, to understand whether the house price cycles are symmetric or not, because the proper means to counteract a potential crisis can be taken. We focus on two measures of the house price cycle asymmetry that we borrow from Andre, Gupta and Mwamba (2019): Deepness represents differences in the magnitude of upswings and downturns. Steepness measures differences in the speed of price changes during upswings and downturns.

The housing market needs to be analysed at different time horizons, because market adjustments in the short, medium and long term vary significantly (see Andre, 2010). The short-term deviations, referred to as the cyclical component (see Razzak, 2001; Andre et al. 2019), are the result of equilibrium distortions, mainly demand shocks. The supply side is regarded as relatively constant in the short term; therefore, higher demand increases

\footnotetext{
1 The mechanism of the global financial crisis was much more complex, Brunnermeier (2009) explains it in detail, but the most important facts that lead to it were significant mortgage financed house purchases in the US which boosted prices and the subsequent abrupt decline of house prices.
} 
prices, whereas lower demand decreases prices. In the short term, demand for given flat sizes and attributes can be considered as a stochastic process, and the mismatch between the desired housing and the one offered on the market generates price fluctuations. The fact that flats meeting the buyer's criteria appear on the market only occasionally can prompt the buyer to make an impulsive decision and pay an excessive price. Other factors, such as the monopolistic pricing strategies of developers (Łaszek, Olszewski, et al., 2016), imperfect information (Wiśniewski, 2008) and subsidy programs (NBP, 2018a), can impact on house price fluctuations. Supply is generated by housing developers and by the owners of housing. Developers follow a predefined strategy and control the timing of market sales, whereas house owners are more prone to herding behaviour when they sell their homes. Most people who sell property have a precise plan to do so, but the exact time of sale is the result of various events. Owners dispose of property mainly to improve their living conditions and to buy a better, newer or larger house. This is possible when housing becomes affordable due to rising incomes and lower mortgage costs and when it is physically available on the primary or secondary market. The decision to sell is triggered by the previously mentioned factors which usually affect many people at the same time and shift the demand and supply curve. This leads to herding behaviour (Brzezicka et al. 2018) and price fluctuations.

In the medium term, the supply side begins to adjust to the demand side because developers deliver more housing to the market. However, excessive demand drives up price. An increase in supply usually raises land and construction costs; therefore, house prices tend to increase in the medium term. The reverse can be observed when the supply of housing becomes excessive or when demand decreases and prices begin to fall. The housing sector adjusts to long-term demand (legislative changes relating to building permits, urban expansion, construction of new factories, movement of labour to the construction sector, etc.) only in the long-term perspective, and house prices grow at the pace of long-term costs and inflation. This is due to the fact that costs follow income levels in the long term.

Various factors affect the house price cycle, and their appearance and strength changes over time, therefore also the shape of the house price cycle can change. The analysis of housing cycles shows that sudden and prolonged declines in prices are very problematic for the economy. They can appear after a long period of slow price growth, but also after a very fast increase in house prices. These two processes may take place one after another when a long-term increase in prices causes strong inflation expectations in the future and an increase in speculative demand.

We try to distinguish in the price time series the structural cycle (trend component), which is relatively mild and captures the natural processes of self-regulation of the sector, and the deviations from this trend. Further on, we analyse how fast prices increase or decrease. We therefore focus on the frequency and the amplitude of the cycle and analyse whether there is a smooth pattern or whether there are sharp changes. We evaluate the short-term and medium-term changes in house prices and the asymmetry of the house price cycle, analysing the steepness and deepness of asymmetric price adjustment. According to Andre, Gupta and Mwamba (2019, p. 2), "Steepness measures the speed at which peaks and troughs are reached. (...) Positive deepness asymmetry implies that peaks are high, while downturns are relatively mild. Negative deepness asymmetry is characterised by modest peaks but deep recessions. (...) Positive steepness asymmetry indicates rapid increases followed by slower declines in prices. (...) Negative steepness asymmetry refers to rapid price falls following slower increases (...)". Explicitly, the deepness measures the cyclical deviation from the trend, while the steepness measures the quarterly change of prices. The two measures the frequency and amplitude, thus important information 

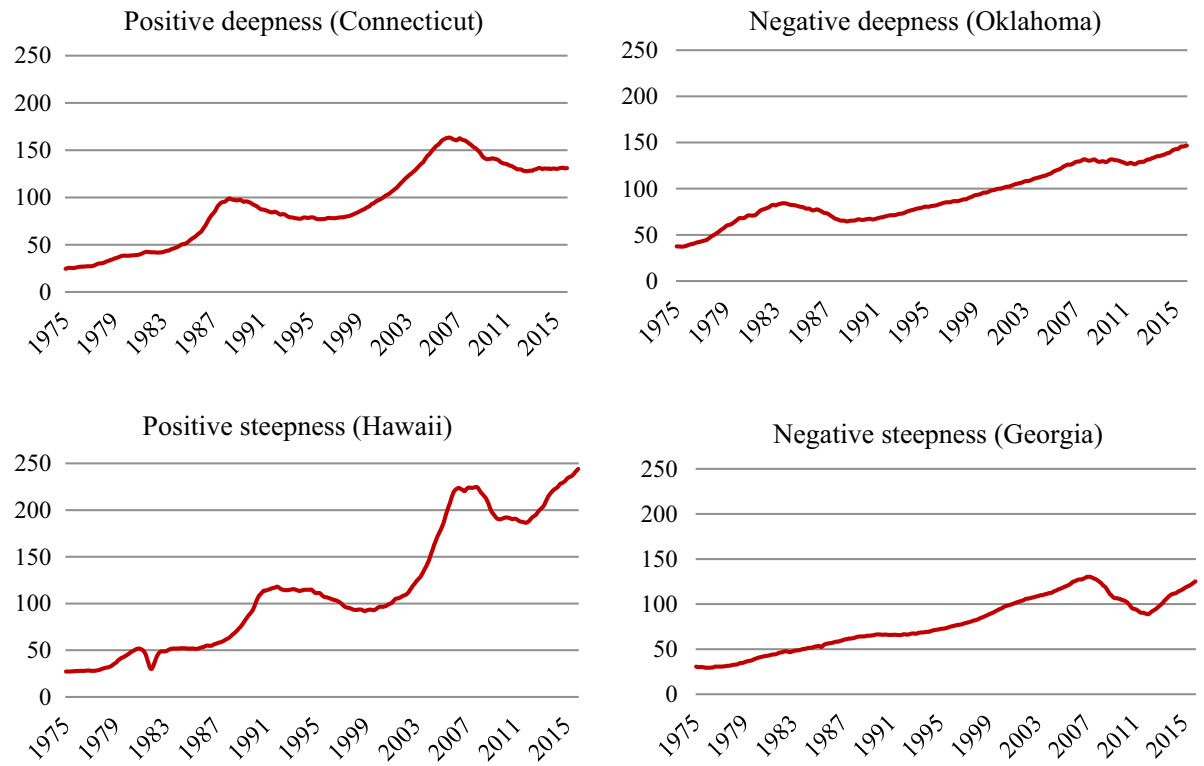

Fig. 1 The Freddie Mac house price index for 1975:01-2015:12, 2000m12=100. Source: Own elaboration based on André et al. (2019, p. 2)

concerning the shape of the cycles. One can assume that the situation is less problematic when positive deepness asymmetry or positive steepness asymmetry occurs, while more severe problems can be expected when negative deepness asymmetry or negative steepness asymmetry occurs. Examples of these phenomena in selected US regions are presented graphically in Fig. 1.

So far we have explained how asymmetry of cycles is measured, but we also need to give examples that help to understand what has caused the asymmetry in a given city, and further what this phenomenon means for that market. We rely here on the results by Andre, Gupta and Mwamba (2019) presented in Fig. 1. Positive deepness which is found in Connecticut means that the housing market observed house price booms that did not end in a bust, but rather a slow decline in prices. After the trough is reached, prices began to rise slowly again. This kind of asymmetry can be considered as a relatively smooth example of house price cycles. While there were some booms, those cooled down slowly, and prices reverted to long-run levels. Most likely relatively few problems were observed in the housing market afterwards. Negative deepness was observed in Oklahoma, where a very long and slow price increase was followed by a significant price decline from around 1983 until 1989. Such a scenario can be also treated as relatively calm, however the prolonged decline in prices had most likely a negative effect on housing developers. As they observed declining prices there were little motives to start new construction. Another important measure of the shape of the cycle is the steepness. Hawaii observed a positive steepness of the cycle, which means that price increases where fast, while the declines rather slow. One can conclude that in this region the market was rather stable, but due to some economic factors from time to time demand increased and lead to significant price growth. The following price decline was smooth and had most likely relatively small negative consequences for the market. However, we observed negative steepness in Georgia, where after decades of slow increases, prices dropped quickly in 2007 and reverted after 2011. Under such a 
scenario, people who took a mortgage in the last years before the downturn got problems, as the value of the mortgage exceeded the value of the house.

We apply the framework described above to analyse the price cycle asymmetry in Poland to elicit detailed information about the functioning of the housing market. We analyse the prices of newly constructed houses and those from the existing stock separately. The term house was used to denote flats in multifamily dwellings. For the sake of shortness, we call the market for newly constructed housing the primary market, while the market for housing form the existing stock is called secondary market. The two markets are strongly related as Brzezicka, et al. (2019) show for the Warsaw housing market, but the impact of economic variables on house prices differs among the two markets types (Leszczyński \& Olszewski, 2017).

The Polish economy is strongly linked to the EU economy; therefore, the Polish housing market could be expected to crash after the Global Financial Crisis. When Poland joined the EU in 2004, the economy accelerated, wages increased and the demand for higher quality housing rose. However, large urban agglomerations continue to experience a shortage of housing. Poland gained access to international capital markets, and seemingly ${ }^{2}$ cheap foreign currency-denominated mortgages became available, which boosted demand. Housing developers were not able to satisfy growing demand and, consequently, house prices increased substantially in 2006-2008. This price growth could be regarded as a bubble, but the bubble never burst. After 2007, prices declined only gradually and only for several years. When the economy stabilised in 2010, prices began to increase slowly, then remained stable, and only minor fluctuations have been observed since.

The aim of this paper was to explain the absence of a classical boom-bust episode, or at least a severe drop in house prices, in Poland. The answer can be found in the specific features of the Polish housing market which are responsible for the differences relative to the surrounding markets. The main differences were prudent mortgage granting criteria during the boom, a nearly continuous increase in wages during the analysed period and two housing subsidy programs. Those factors will be explained in greater detail in Sect. 5.

The paper is organized as follows: The relevant literature is reviewed in Sect. 2, data and econometric methods are described in Sect. 3. The empirical analysis is presented in Sect. 4, and the results are discussed and conclusions are formulated in Sect. 5.

\section{Literature review}

The long-term relationship between house prices and economic variables was analysed by Abraham and Hendershott (1996), Gallin (2006), Malpezzi (1999), Capozza et al. (2002), Lee and Song (2015), and Lambertini et al. (2017). Abraham and Hendershott (1996) divided the analysis into a cointegration relationship in the long term and adjustments in the short term. The Wheaton DiPasquale (1992) model provides the theoretical, long term background for an analysis of cycles. The model describes the relationship between space and rents which influences prices and, consequently, construction through interest rates. The above factors coupled with depreciation determine housing supply. The model was designed for the commercial rental market, but it can

\footnotetext{
${ }^{2}$ Łaszek et al. (2016a) discussed the problems resulting from the depreciation of the Polish currency against the EUR and CHF.
} 
also be applied to the housing market, including in Poland where owner-occupied housing dominates. For the needs of this analysis, rented space has to be substituted with owner-occupied housing space or housing units. In this setting, the supply of new flats increases in response to a higher demand for housing units (rather than space measured in $\mathrm{m}^{2}$ ). The construction process takes time, and prices increase until new supply (including pre-sale contracts) reaches the market. According to Andre (2010), the main drivers of house price cycles in the OECD countries on the demand side are the real disposable income of households, interest rates and the evolution of the mortgage market. The determinants of supply are land availability, permits, infrastructure and profits. Hott (2009) analysed house prices in six highly developed countries and found that house prices fluctuated more than fundamentally justified, which he interpreted as bubbles. He also proposed a model for detecting such bubbles. The cited author observed that buyers and financing institutions do not rely only on fundamentals, which leads to substantial over- and under-valuations (cf. Shi, 2017; Kim and Lim (2016) and has important implications for the present study.

We should also point out that according to Quan and Quigley (1991), and Geltner (2015) valuation indices are smoother than the price indices, and what is even more problematic, they lag behind the transaction price index. Brown and Matysiak (2000, p. 51) explain that in the commercial property sector sticky valuations can be observed, which results from three facts: some valuations are done on an annual basis, not quarterly; sometimes valuers do not consider some information to be important to adjust prices; during a downturn the clients of the valuer might want that the value adjusts slowly to the new equilibrium. While those results consider the commercial property market, it is likely that similar problems occur when banks value a large portfolio of housing units. When the price boom already comes to an end, valuations can still show a growing price trend. And vice-versa, when the through is reached and the economy starts to expand, bank valuations might be below the market prices, which will decrease their willingness to issue new mortgages.

The asymmetry of price cycles can be analysed by determining the deepness asymmetry and the steepness asymmetry (André et al. 2019, p. 2) which have been described in the Introduction. In the literature, deepness is also referred to as depth (Razzak, 2001; Verbrugge, 1997, 1998). Deepness measures the relative magnitude of peaks and troughs, whereas steepness measures the rate at which peaks and troughs are reached (André et al. 2019, p. 2). Asymmetry is measured with the use of two tests: the Triples test and the entropy test. The Triples test is a nonparametric asymmetry test designed by Randles et al. (1980). The Triples tests has been used by Verbrugge (1997), Razzak (2001) and Cook (2006) to measure cycle asymmetry.

Verbrugge (1997) analysed asymmetry in view of macroeconomic variables based on quarterly post-war US data, including the unemployment rate, index of total good-producing hours, total private employment, industrial production index, real GDP, real consumption, real investment, real government spending, real net exports, index of coincident indicators, and CPI. Razzak (2001) relied on the Triples tests to detect asymmetries in the U.S. as well as international GDP fluctuations. A similar analysis was undertaken by Belaire-Franch and Contreras (2003). Both studies examined asymmetry in six countries (US, UK, Japan, Germany, Australia and New Zealand). Cook (2006, p. 2067) investigated asymmetry in regionally disaggregated UK house prices and then examined data that were further disaggregated according to age or vintage of the housing stock. Yilanci (2012) used the Triples tests to examine the asymmetric behaviour of macroeconomic aggregates for Bulgaria, Croatia and Romania. André et al. (2019) investigated asymmetry in US housing price cycles at the state and metropolitan statistical area (MSA) level. 
One of the first studies of house cycles in Poland was carried out by Trojanek (2011). This study focused on quarterly offer prices for 6 large cities, covering 1996-2011, and found that all the cities have similar phases of the cycle, however they differ in length. The results can be seen as a first attempt to study the asymmetry of the house price cycles in various cities. However, according to the best of the authors' knowledge, the asymmetry of price cycles on the Polish real estate market has not been examined with the use of the Triples test or the entropy test. André et al. (2019, p. 3 ) concluded that "asymmetry in housing cycles may result from asymmetry in the determinants of housing prices and/or from non-linearity in the relationships between these determinants and housing prices". Similar observations were made by Batóg and Foryś (2010); Gdakowicz and Hozer (2012), Foryś (2009), Foryś (2013a), Foryś (2013b), and Trzęsiok (2013). Bełej (2012) and Bełej and Kulesza (2011, 2013) used asymmetry and bifurcation indicators in a time series analysis of housing prices to develop mathematical models from the point of view of catastrophe theory. They found that the dynamics of real estate prices was non-homogeneous. Prices remained stable in the long-term, and rapid and short-term fluctuations were observed in unstable states. Kulesza and Bełej (2015) and Bełej (2018) evaluated the asymmetry of price cycles on the real estate market with the use of a non-linear mathematical function describing the behaviour of a harmonic oscillator. They analysed the phase of rapid price increases, followed by an asymptotic return to long-term stability characterised by series of impulses of decreasing magnitude.

Many of the abovementioned empirical studies use the repeated sales prices index or the hedonically corrected house price index to study the house price cycles. However, in order to use such data instead of the mean transaction price, it needs to be available. As concerns the housing market in Poland, the repeated sales index is still under development. The recent studies propose how to generate such an index (Czerski et al. 2017; Głuszak et al. 2018) and motivate why such an index should be used (Hill \& Trojanek, 2020). But the repeated sales methodology has not been adopted with significant success in Poland, mainly because of concern regarding the relative low frequency of transactions on the housing market in most metropolitan areas and the small sample of repeated sales (Czerski et al. 2017). It should be also mentioned that according to Balk et al., 2013 the sample selection bias is a significant limitation of this method, especially in a rather still developing housing market. Hill and Trojanek (2020), who analyse house price data for Warsaw, point out that such an index is unreliable, suffering from the sample selection bias, and prone to significant revisions when new periods are added to the dataset. Hill and Trojanek (2020) compare different methods to generate a house price index and find that the hedonic index is a robust method. The hedonic index method was applied in Poland to analyse house prices in Warsaw by Widłak and Tomczyk (2010) and Olszewski et al. (2017), and by Trojanek (2009, 2012, 2018) to analyse the housing market in Poznań. Given that the hedonic index is a robust measure of house price changes, it should be used for the analysis of the asymmetry of house price cycles. However, there is no hedonically corrected price index for the primary housing market, because the price changes in that market result mostly from the monopolistic competition of developers who sell rather similar flats at various prices at a given time to different buyers (see Łaszek, Olszewski, et al., 2016). To sum up, we apply the second best solution, that is we use the mean transaction prices to study the house price asymmetry in Poland. 


\section{Data and methods}

\subsection{Triples test}

The time series has to be decomposed for the Triples test into the trend part and the cycle part. This can be achieved with the use of the Hodrick-Prescott filter (HP) (Verbrugge, 1997; Cook, 2006; André et al. 2019, p. 4). Despite the criticism of the HP filter in recent literature (see Hamilton, 2018), the previously proposed methodology was used in this study. In the first step, time series have to be log transformed. Deepness is calculated based on detrended time series, and steepness is determined based on first difference data.

Formally, $x_{1}, x_{2}, \ldots, x_{N}$ denote a random sample drawn from $F(x-\theta)$, where $F(\bullet)$ is a cumulative distribution function for a continuous population with $F(0)=\frac{1}{2}$ and $\theta$ is the median of the $x$ population. Function $f^{*}\left(x_{i}, x_{j}, x_{k}\right)$ is defined as follows:

$$
f^{*}\left(x_{i}, x_{j}, x_{k}\right)=\frac{1}{3}\left[\begin{array}{c}
\operatorname{sign}\left(x_{i}+x_{j}-2 x_{k}\right) \\
+\operatorname{sign}\left(x_{i}+x_{k}-2 x_{j}\right) \\
+\operatorname{sign}\left(x_{j}+x_{k}-2 x_{i}\right)
\end{array}\right],
$$

where

$$
\operatorname{sign}(x)=\left\{\begin{array}{c}
1 \text { if } x>0 \\
0 \text { if } x=0 \\
-1 \text { if } x<0
\end{array}\right.
$$

It should be noted that $f^{*}\left(x_{i}, x_{j}, x_{k}\right)$ can only be $\frac{1}{3}, 0,-\frac{1}{3}$. In this case, $\left(x_{i}, x_{j}, x_{k}\right)$ forms the right triple if $f^{*}\left(x_{i}, x_{j}, x_{k}\right)=\frac{1}{3} ;\left(x_{i}, x_{j}, x_{k}\right)$ forms the left triple if $f^{*}\left(x_{i}, x_{j}, x_{k}\right)=-\frac{1}{3}$. When $f^{*}\left(x_{i}, x_{j}, x_{k}\right)=0$, the triple is neither right skewed nor left skewed, however, such an outcome has a zero probability when sampling from a continuous population. The proposed test statistics is the $U$ statistics given by:

$$
\hat{\eta}=\left(\begin{array}{c}
N \\
3
\end{array}\right)^{-1} \sum_{i<j<k} f^{*}\left(x_{i}, x_{j}, x_{k}\right)
$$

Therefore:

$$
\hat{\eta}=\frac{[(\text { number of right triples })-(\text { number of left triples })]}{\left[3\left(\begin{array}{c}
N \\
3
\end{array}\right)\right]} .
$$

and

$$
\mathrm{E}(\hat{\eta})=\eta=\operatorname{Pr}\left\{x_{1}+x_{2}-2 x_{3}>0\right\}-\operatorname{Pr}\left\{x_{1}+x_{2}-2 x_{3}<0\right\},
$$

with

$$
\operatorname{var}(\hat{\eta})=\left(\begin{array}{c}
N \\
3
\end{array}\right)^{-1} \sum_{c=1}^{3}\left(\begin{array}{l}
3 \\
c
\end{array}\right)\left(\begin{array}{c}
N-3 \\
3-c
\end{array}\right) \xi_{c}
$$

where: 


$$
\xi_{c}=\operatorname{var}\left[f_{c}^{*}\left(x_{1}, \ldots, x_{c}\right)\right]
$$

and.

$$
f_{c}^{*}\left(x_{1}, \ldots, x_{c}\right)=E\left[f_{c}^{*}\left(x_{1}, \ldots, x_{c}, x_{c+1}, \ldots, x_{3}\right)\right] .
$$

Assuming that $\sigma_{A}^{2}=9 \xi_{1}$ and $o_{N}^{2}=o_{A}^{2}+o(1)$, Randles et al. (1980) used the Slutsky Theorem to show that $N^{1 / 2}=\left(\eta^{\prime}-\eta\right) / \sigma_{A}$ also has a standard normal limiting distribution. The following assumption was tested in this study:

$$
H_{0}: \hat{\eta}=0 \text { versus the alternative } H_{1}: \hat{\eta} \neq 0 .
$$

The Triples test is used to test the hypothesis that the distribution is symmetric when the unknown median $\theta$ is tested against a broad class of asymmetric alternatives. The Triples test is a two-sided test, but it can be used as a one-sided test. Randles et al. (1980) demonstrated that the class of asymmetric distributions for which $\eta=0$ is small.

The two asymptotic normal forms yield an asymptotically distribution-free test (8) provided that $\sigma_{N}$ and $\sigma_{A}$ are replaced by consistent estimators $\hat{\sigma}_{N}$ and $\hat{\sigma}_{A}$ in the appropriate expressions. Randles et al. (1980) demonstrated that the resulting tests are consistent if and only if $\hat{\eta} \neq 0$.

The quantities $\xi_{1} \xi_{2}$ and $\xi_{3}$ are expressed in terms of probabilities and are computed in the following order:

$$
\begin{gathered}
\xi_{1}=\operatorname{var}\left[f_{1}^{*}\left(x_{1}\right)\right], \text { with } f_{1}^{*}(x)=E\left[f^{*}(\bullet)\right] . \\
\xi_{1}=\frac{1}{N} \sum_{i=1}^{N}\left(f_{1}^{*}\left(x_{i}\right)-\hat{\eta}\right)^{2},
\end{gathered}
$$

where

$$
f_{1}^{*}\left(x_{i}\right)=\left(\begin{array}{c}
N-1 \\
2
\end{array}\right)^{-1} \sum_{\substack{j<k \\
j \neq i \neq k}} \sum f^{*}\left(x_{i}, x_{j}, x_{k}\right) .
$$

and

$$
\xi_{2}=\left(\begin{array}{c}
N \\
2
\end{array}\right)^{-1} \sum_{j<k} \sum_{i=1}^{N}\left(f_{2}^{*}\left(x_{j}, x_{k}\right)-\hat{\eta}\right)^{2},
$$

where

$$
f_{2}^{*}\left(x_{j}, x_{k}\right)=\frac{1}{N-2} \sum_{\substack{i=1 \\ j \neq i \neq k \\ i \neq k}} f^{*}\left(x_{i}, x_{j}, x_{k}\right) .
$$

and 


$$
\xi_{3}=\frac{1}{9}-(\hat{\eta})^{2}
$$

Each $\xi_{i}$ and $\widehat{\xi}_{i}$ are replaced in the expression for $\sigma_{N}$ and $\sigma_{A}$ to produce estimators $\hat{\sigma}_{N}$ and $\hat{\sigma}_{A}$. Both estimators are consistent because each $\hat{\xi}_{i}$ is written as a linear combination of the $U$ statistics. To test the hypothesis in (8), the Triples test is defined based on $T_{1}=N^{1 / 2} \hat{\eta} / \hat{\sigma}_{N}$ and an associated text based on $T_{2}=N^{1 / 2} \hat{\eta} / \hat{\sigma}_{A}$. Therefore, $H_{0}$ is rejected because $\left|T_{i}\right|>Z_{(\alpha / 2)}, i=1,2$, where $Z_{(\alpha / 2)}$ is the upper percentile of the standard normal distribution. These tests are asymptotically distribution-free provided that the underlying distribution is not degenerate.

\subsection{Entropy test}

The entropy test of asymmetry described by Racine and Maasoumi (2008) is based on the normalization of the Bhattacharya-Helliger statistic measure of dependence $S_{p}$ given by:

$$
S_{p}=\frac{1}{2} \int_{-\infty}^{+\infty}\left(f_{1}^{1 / 2}-f_{2}^{1 / 2}\right)^{2} d y,
$$

where: $f_{1}=f(y)$ is the marginal density of a continuous stationary random variable $Y_{i}$, and $f_{1}=f(\hat{y})$ for $\hat{Y}_{i}$, where $\hat{Y}_{i}$ denotes $Y_{i}$ rotated around its mean i.e. $\widehat{Y}_{i}=-Y_{i}+2 E\left(Y_{i}\right)$. Vector $Y_{i}$ is parametrically asymmetric around the mean if $f(y) \equiv f(\hat{y})$ which corresponds to the following test of asymmetry:

$$
H_{0}: f(y)=f(\hat{y}) \text { for all } y \text { versus the alternative. } H_{1}: f(y) \neq f(\hat{y})
$$

The calculations for the entropy test were performed in R.

\section{Empirical framework}

We analyse mean transaction prices on the primary and secondary real estate market in the 17 largest Polish cities between 3Q2006 and 3Q2018. The data was obtained from the National Bank of Poland (NBP 2018b, see link for data). We use mean transaction prices, because such prices are available for both the primary and the secondary market.

We are aware of the potential limitations of applying the mean price data and want to present the arguments why we still chose this approach. Many of the empirical studies mentioned in the literature review use hedonically corrected prices or repeated sales prices, which means that the house price data is robust to changes in the composition of the analysed sample in each quarter. The composition of the sample can change over the cycle, in which case it is possible that the mean price trajectory differs from the quality adjusted one. For example during an upswing people want to buy larger flats, while they prefer smaller ones during a downswing. Given that smaller flats usually have a higher price per square meter that the larger ones, this could make the price growth and also the price decline flatter. However, we want to use the same kind of price data for the primary and the secondary market, such that we can compare our findings for both markets. As explained in the literature review, the repeated sales index is still an unreliable methodology to assess house prices in Poland. The hedonic index would be the best solution, but it cannot be used for the primary housing market. To strengthen our theoretical arguments we compared the quarterly mean and hedonic price data on the secondary market in all cities 
and found that the two series show the same medium and long run properties. There are short-term deviations between the two series, but those can be neglected when we focus on cycles (see for example the figures in NBP 2018b). This means that the mean transaction price data are well suited for our analysis.

The real house prices, the trend inferred with the HP filter and a linear trend are presented in the figures below. The data in the figures relate to the primary market. Selected graphic elements for the secondary market are presented in Appendix 1 for greater readability. The characteristic features of price cycles on the Polish real estate market are described first.

Pre-sale contracts are widely applied on the primary market in Poland. This solution improves the elasticity of supply, but it does not satisfy housing needs until new dwellings are commissioned for use. According to Łaszek et al. (2018), the Polish market had undergone three cycles between 1994 and 2018. The cycle covering the period of 1994-2003 was caused by the transition from a centrally planned to a market-oriented economy during which State-owned cooperatives were replaced by private housing developers. This cycle, termed as the "zero" cycle, was not analysed because quarterly data for all 17 major cities became available only in 2007. The first cycle in a fully market-oriented economy (2004-2009) began upon Poland's accession to the EU. Poland's membership in the EU increased wages and the affordability of higher-quality housing. Demand rapidly surpassed supply, which prompted developers to increase prices. Interestingly, the price bubble did not burst - the demand did not decline because mortgage takers experienced financial difficulties, but because the Global Financial Crisis instilled fear in the Polish economy. Banks remained cautious and offered mortgages to more affluent consumers who repaid their loans on time. New construction projects were put on hold for several quarters, and only housing units that had been under construction were completed. Borrowers did not observe significant economic shocks because wages continued to increase and only a minor rise in unemployment was observed. Most mortgages were taken out by the wealthier part of the population. However, foreign currency denominated mortgages could have caused a shock when the PLN/CHF exchange rate dropped by nearly $40 \%$ in 2009 . Fortunately, the Swiss National Bank lowered its interest rate to zero (see Łaszek, Augustyniak, et al., 2016 for more details). Poland has only adjustable interest rate mortgages; therefore, the exchange rate shock was mitigated by the decrease in the interest rate, and monthly mortgage payments did not change substantially. In contrast, Hungarian consumers had been offered fixed rate mortgages, therefore, the interest rate for the client did not decrease when the Swiss National Bank rate had been reduced, and the foreign currency shock contributed to an increase in monthly payments. However, collateral value decreased, and mortgage debt exceeded the assessed value of many homes. As a result, many home-owners were prevented from selling their property in fear of a financial loss. These processes were described in detail by Łaszek, Augustyniak, et al. (2016). The second and present market cycle began in 2010, and it can be considered as the first cycle on a mature housing market. The buyers and the sellers are well informed, and consumers can chose between different offers. Some consumers can afford to make substantial down payments, which gives them leverage during price negotiations with developers. Developers have gained experience and have acquired sufficient capital and land to increase construction in the medium term without causing significant price hikes. However, the increase in prices should follow the increase in construction costs which are determined by the prices of land, construction material and wages.

The data for the study were relatively scarce; therefore, the presented analysis covers only the end of the first cycle and a significant portion of the second cycle. To the authors' 


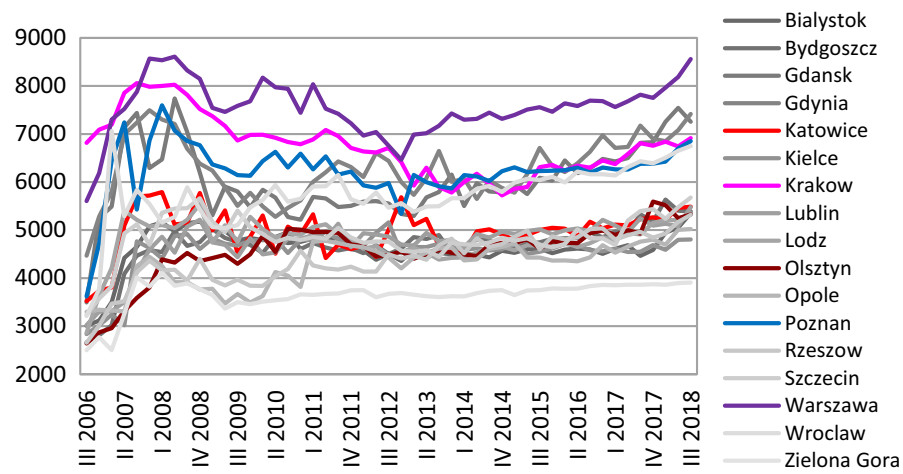

Fig. 2 Real prices on the primary market. Source: own elaboration

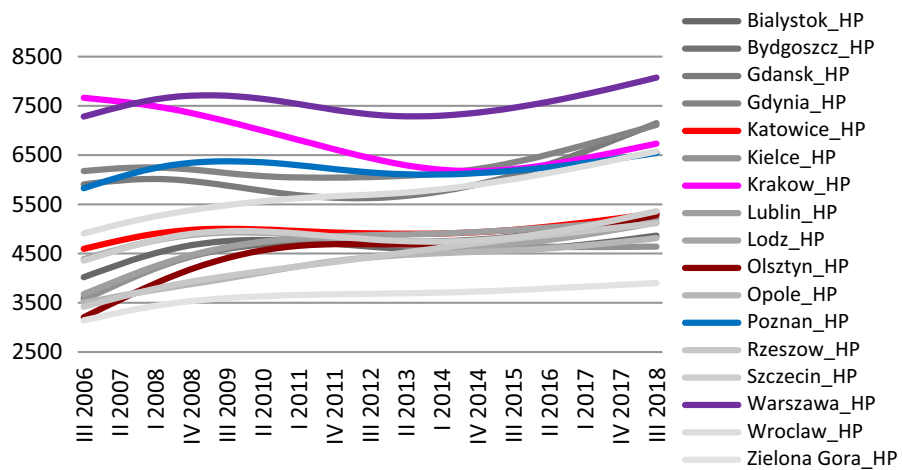

Fig. 3 Long-term trends, HP filter-primary market Source: own elaboration

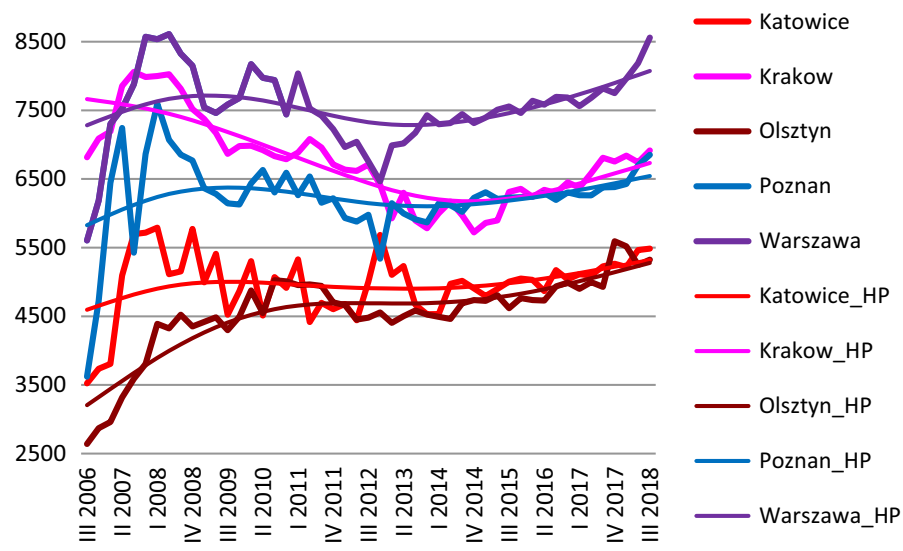

Fig. 4 Prices and the trend component-price gap. Source: own elaboration 


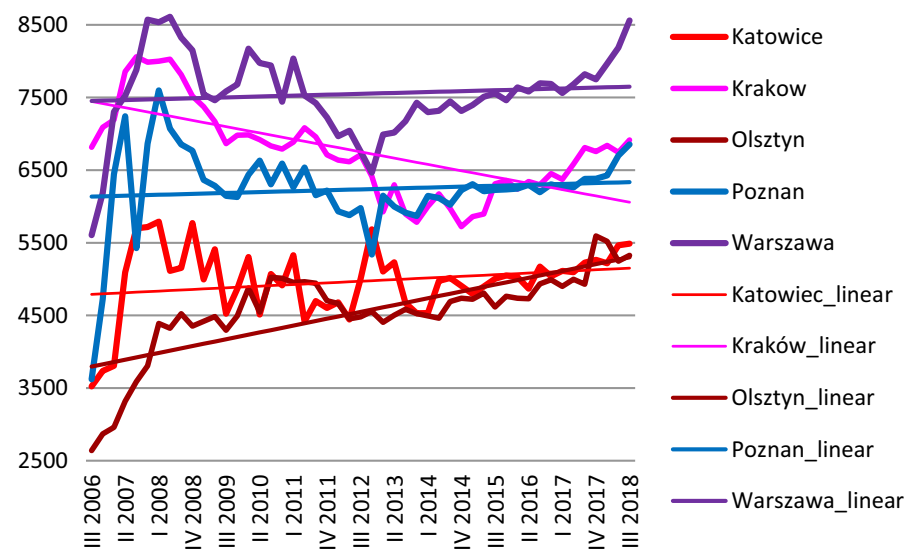

Fig. 5 Linear trendline. Source: own elaboration

best knowledge, the analysed database is the longest available set of quarterly data for all analysed cities. It should also be noted that the main focus of the study was on the cyclical component which can be calculated from the available time series.

An econometric analysis of the time series requires several transformations and a brief explanation. The prices in PLN per $\mathrm{m}^{2}$ of housing on the primary market are shown in Fig. 2. The trend component was first calculated with the Hodrick Prescott filter, and it is presented in Fig. 3. For five cities, both series were presented in Fig. 4 to simplify the graphic analysis of cyclic price deviations from the trend. These cities were selected to eliminate the overlap between time series and to improve readability. The linear trendline is illustrated in Fig. 5.

During the first cycle, prices deviated significantly from the trend component in all cities, whereas in the second and present cycle, the cyclical component closely follows the trend component. In macroeconomics, a deviation of the cycle from the GDP trend is referred to as the output gap (see Helbling, 2005; Roubini, 2006; Anundsen et al. 2016). On the housing market, this deviation can be interpreted as sign of a bubble or a bubble burst when the gap changes from a positive to a negative value (Tyc, 2013). Chen (2016, p. 109) applied a multiple-factor panel data model to demonstrate that market failure is largely associated with a high ratio of persistent components in the gap between price and equilibrium. The presented data could suggest that house prices were too low at the beginning of the analysed period. However, this was not the case, and the processed data are more likely to indicate a structural break in the market. As stated in the Introduction, there was hardly any new construction before 2004, and developers began to emerge gradually in the following years. After Poland had joined the EU, wages increased rapidly to previously unimaginable levels, which helped drive the demand for housing. Demand rose to an unprecedented level that is presently regarded as normal. Therefore, a price gap did not occur at the beginning of the analysed period. However, prices increased rapidly when housing became available on free market principles.

The above observations indicate that the Polish real estate market has matured and deepened; therefore, supply responds more rapidly to changes in demand. A linear trend was applied to prices to show their long-term evolution. Upward or neutral long-term trends were noted in cities with lower prices, whereas a downward trend was observed in Kraków. 

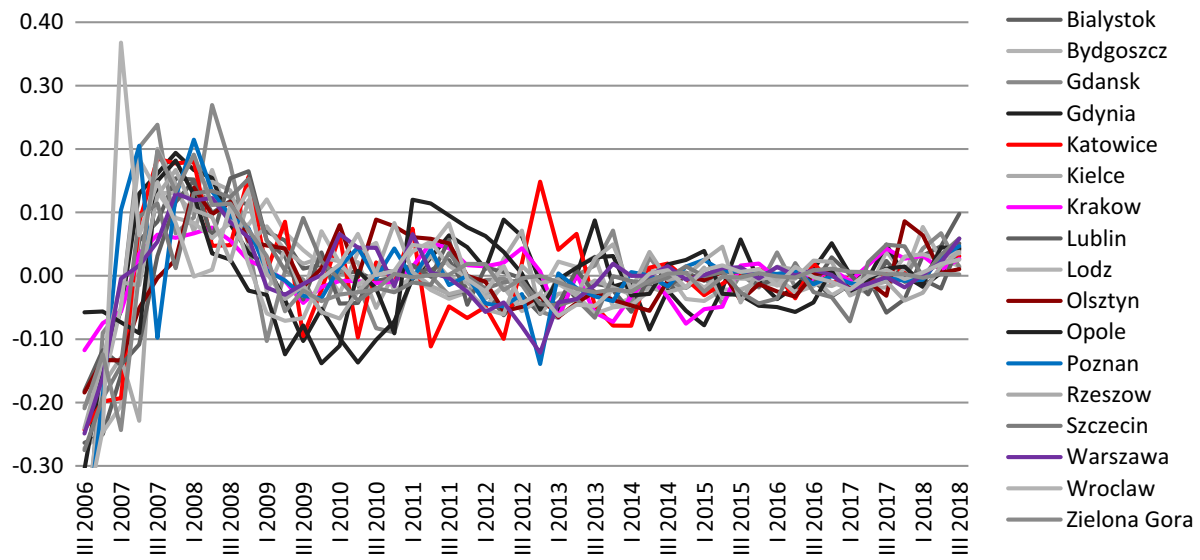

Fig. 6 Detrended data for analysing the deepness asymmetry on the primary market. Source: own elaboration
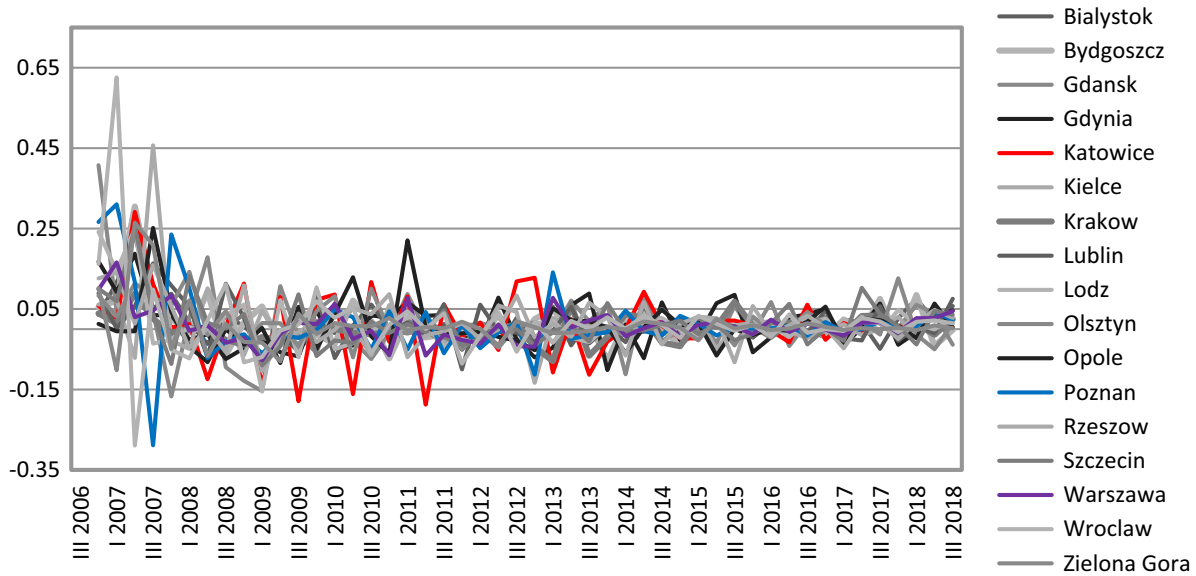

Fig. 7 First difference data for analysing the steepness asymmetry on the primary market. Source: own elaboration

It is highly probable that prices on the Kraków market had been pushed to extreme levels during the first cycle, converged to a new equilibrium, and began to rise again in recent years. The long-term trend has to be interpreted with caution because the available data cover only a period of 12 years. However, these findings provide some insights into how the market could evolve in the future.

Detrended data for analysing the deepness asymmetry on the primary market are presented in Fig. 6. First difference data for analysing the steepness asymmetry on the primary market are shown in Fig. 7.

Time series were analysed in detail. Descriptive statistics were examined in view of the coefficient of skewness. Data distribution was assessed for normality with the Shapiro-Wilk test and D'Agostino's K-squared test which measures departure from normality based on skewness. The results are presented in Appendix 2. The skewness/asymmetry of 
Table 1 Results of D'Agostino's test—primary market

\begin{tabular}{|c|c|c|c|c|}
\hline & \multicolumn{4}{|l|}{ Primary market } \\
\hline & \multicolumn{2}{|l|}{ Deepness } & \multicolumn{2}{|l|}{ Steepness } \\
\hline & Z-test, Skewness & $P$ value & Z-test, Skewness & $P$ value \\
\hline Bialystok & -3.071 & $0.00213^{*}$ & 4.982 & $0.00000^{*}$ \\
\hline Bydgoszcz & -3.158 & $0.00159^{*}$ & 5.113 & $0.00000 *$ \\
\hline Gdansk & -3.517 & $0.00044^{*}$ & 3.899 & $0.00010^{*}$ \\
\hline Gdynia & -1.345 & 0.17870 & 1.824 & 0.06814 \\
\hline Katowice & 0.725 & 0.46830 & 0.205 & 0.83800 \\
\hline Kielce & -1.446 & 0.14820 & 6.586 & $0.00000 *$ \\
\hline Krakow & -1.646 & 0.09984 & 0.446 & 0.65550 \\
\hline Lublin & 0.385 & 0.70050 & 1.067 & 0.28580 \\
\hline Lodz & -4.776 & $0.00000^{*}$ & 3.991 & $0.00007 *$ \\
\hline Olsztyn & 0.966 & 0.33410 & 2.355 & $0.01853^{*}$ \\
\hline Opole & 1.408 & 0.15930 & 4.548 & $0.00001^{*}$ \\
\hline Poznan & -4.281 & $0.00002 *$ & 2.102 & $0.03555^{*}$ \\
\hline Rzeszow & -1.524 & 0.12750 & 1.308 & 0.19080 \\
\hline Szczecin & -2.526 & $0.01152 *$ & 3.894 & $0.00010^{*}$ \\
\hline Warszawa & -3.162 & $0.00157^{*}$ & 2.725 & $0.00643 *$ \\
\hline Wroclaw & -1.376 & 0.16880 & 5.964 & $0.00000 *$ \\
\hline Zielona Gora & 8.315 & $0.00000^{*}$ & 5.188 & $0.00000 *$ \\
\hline
\end{tabular}

${ }^{*}$ Skewness for $p<0.05$ (if $p>p *$ H0 postulating that distribution is not skewed is true)

time series was analysed with the use of the asymmetry coefficient, and it revealed variations in skewness. The vast majority of the time series tested for deepness had left-skewed distribution, and the time series tested for steepness had right-skewed distribution. The Shapiro-Wilk test revealed normal distribution in a minority of cases; however, this does not preclude analyses with the use of the Triples test and the entropy test. D'Agostino's test demonstrated an absence of normal distribution, in particular on the secondary market, due to market asymmetry. The results of the above analyses should be interpreted separately because they are based on different assumptions and have different objectives.

The results of the Triples and entropy tests are presented below. The results of the Triples test are presented in Table 1 for the primary market and in Table 2 for the secondary market. The results of the entropy test are presented in Table 3 for the primary market and in Table 4 for the secondary market. In asymmetry tests, significant results (where the null hypothesis postulating the symmetry of the time series was rejected) are marked with an asterisk. The number of asterisks denotes different levels of significance.

The analysis revealed asymmetry in a small number of the analysed price series. The Triples test and the entropy test produced the same number of asymmetric series, but, interestingly, these series were not identical. According to Andre, Gupta and Mwamba (2019), the Entropy test detects more cases of asymmetry. In this study, the Triples test detected 8 out of $68^{3}$ asymmetric series, whereas the entropy test detected 8 out of 68 asymmetric

\footnotetext{
3 There are 68 series because 17 cities were analysed on the primary and secondary markets, for both deepness and steepness, $17 * 2 * 2=68$.
} 
Table 2 Results of D’Agostino's test—secondary market

\begin{tabular}{|c|c|c|c|c|}
\hline & \multicolumn{4}{|l|}{ Secondary market } \\
\hline & \multicolumn{2}{|l|}{ Deepness } & \multicolumn{2}{|l|}{ Steepness } \\
\hline & Z-test, Skewness & $P$ value & Z-test, Skewness & $P$ value \\
\hline Bialystok & -4.040 & $0.00005^{*}$ & 2.495 & $0.01260^{*}$ \\
\hline Bydgoszcz & -3.397 & $0.00068^{*}$ & 3.779 & $0.00016^{*}$ \\
\hline Gdansk & -3.322 & $0.00089 *$ & 3.566 & $0.00036^{*}$ \\
\hline Gdynia & -5.735 & $0.00000 *$ & 5.407 & $0.00000^{*}$ \\
\hline Katowice & -2.518 & $0.01180 *$ & 3.338 & $0.00084^{*}$ \\
\hline Kielce & -4.223 & $0.00002 *$ & 3.948 & $0.00008^{*}$ \\
\hline Krakow & -2.707 & $0.00680^{*}$ & 4.470 & $0.00001 *$ \\
\hline Lublin & -3.388 & $0.00070^{*}$ & 2.430 & $0.01512^{*}$ \\
\hline Lodz & -4.906 & $0.00000^{*}$ & 6.457 & $0.00000^{*}$ \\
\hline Olsztyn & -4.494 & $0.00001^{*}$ & 4.778 & $0.00000^{*}$ \\
\hline Opole & -2.199 & $0.02789 *$ & 2.537 & $0.01119^{*}$ \\
\hline Poznan & -3.502 & $0.00046^{*}$ & 2.889 & $0.00386^{*}$ \\
\hline Rzeszow & -2.537 & $0.01117^{*}$ & 5.990 & $0.00000^{*}$ \\
\hline Szczecin & -3.719 & $0.00020^{*}$ & 3.702 & $0.00021^{*}$ \\
\hline Warszawa & -3.853 & $0.00012^{*}$ & 2.187 & $0.02875^{*}$ \\
\hline Wroclaw & -1.034 & 0.30110 & 0.427 & 0.66940 \\
\hline Zielona Gora & -2.274 & $0.02298 *$ & 4.042 & $0.00005 *$ \\
\hline
\end{tabular}

* Skewness for $p<0.05$ (if $p>p *$ H0 postulating that distribution is not skewed is true)
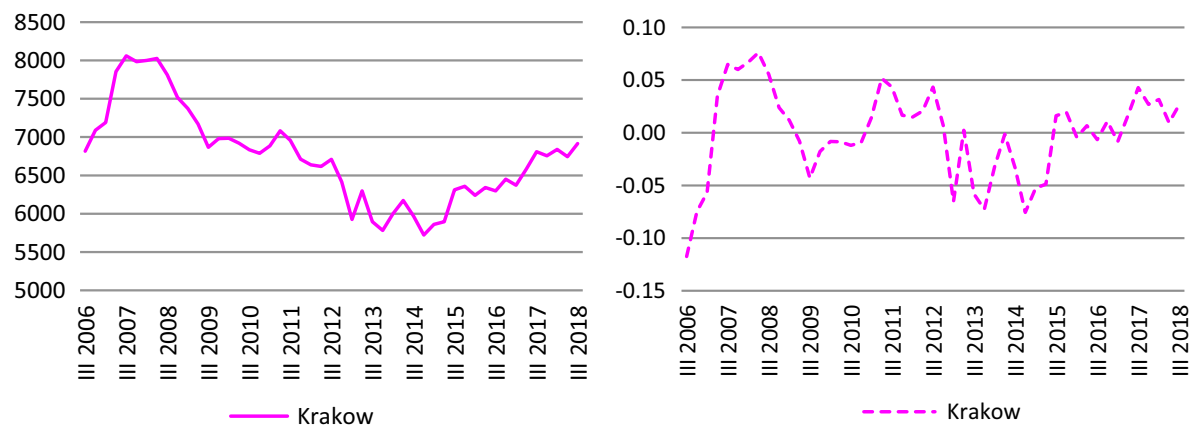

Fig. 8 Kraków, primary market-real prices and the cyclic component for deepness. Source: own elaboration

series. The results of the Triples test will be discussed first. The test revealed deepness on the primary market in Kraków and steepness on the secondary market in Olsztyn. No signs of deepness were found on the secondary market, but steepness was detected in Katowice, Lublin, Lodz, Olsztyn, Szczecin and Zielona Gora. Steepness was detected on both markets only in Olsztyn. The replication of the test with entropy methods did not confirm the cases that were detected in the Triples test, with Olsztyn and Szczecin being the only two exceptions. On the primary market, deepness was identified in Bydgoszcz and steepness was detected in Katowice, Lublin and Olsztyn. On the secondary market, deepness was 

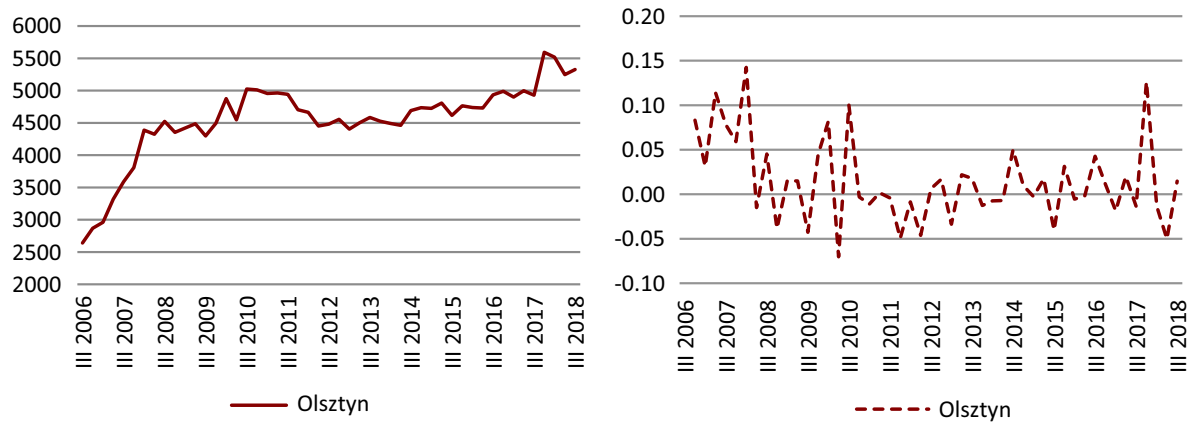

Fig. 9 Olsztyn, primary market-real prices and price increase for deepness. Source: own elaboration
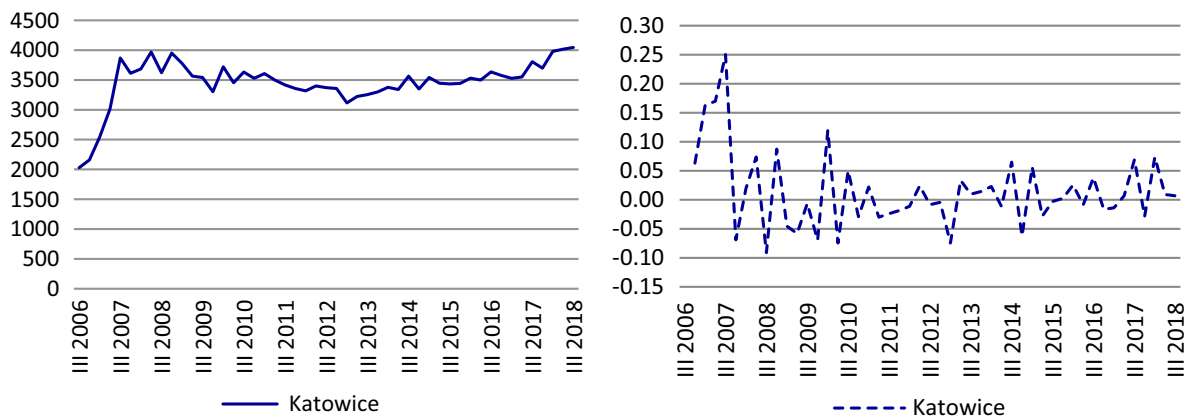

Fig. 10 Katowice, psecondary market-real prices and price increase for steepness. Source: own elaboration

found in Szczecin and steepness-in Katowice. The entropy test detected steepness on both markets only in Katowice.

Three selected examples of asymmetric series are presented below. The series for Kraków are presented in Fig. 8 the series for Olsztyn-in Fig. 9; the series for Katowicein Fig. 10. The observations made on the Polish real estate market are less dynamic and asymmetrical than the American examples discussed in the Introduction.

\section{Discussion and conclusions}

The empirical analysis revealed low values of asymmetry indicators on the Polish housing market. Signs of deepness and steepness were identified only in isolated cases, independently of the applied empirical method. For primary market data, the Triples test revealed deepness in Krakow and steepness in Olsztyn. For secondary market data, the Triples test provided evidence for steepness in Katowice, Lublin, Lodz, Olsztyn, Szczecin and Zielona Gora. The replication of the test with the entropy method produced the same conclusions, and data were replicated only for Olsztyn and Szczecin. On the primary market, deepness was found in Bydgoszcz, and steepness was detected in Katowice, Lublin and Olsztyn. On the secondary market, deepness was found in Szczecin and steepness-in Katowice. 
We should mention that the results on mean transaction prices, while some authors argue to use hedonically corrected or repeated sales prices. However, as discussed in the beginning of Sect. 4 , we wanted to analyse the primary and the secondary housing market, and in this case we could only use mean transaction prices to get comparable results.

Knowing our research limitations we want to put our results into the context of the results that Andre, Gupta and Mwamba (2019, pp 8 and 9) obtained for the US: They state: "Taking into account the results of the two tests, (...) deepness asymmetry is found in 39 out of the 51 states (including the District of Columbia) and 238 out of the 381 MSAs. Steepness asymmetry (...) is found in 40 states and 257 MSAs." The results of the Triples test and the Entropy test that we apply to the house price cycles in the 17 largest cities in Poland are quite different: On the primary housing market we find steepness asymmetry in 3 out of the 17 cities, and deepness asymmetry in 2 out of the 17 cities. On the secondary housing market we find steepness asymmetry in 6 out of the 17 cities, and deepness asymmetry only in 1 out of the 17 cities. While house price asymmetry can be observed in the majority of US states and MSAs, it seems to be rather a seldom phenomenon in Poland. We want to explain our findings and their reasons in more detail.

The cities characterised by house price cycle asymmetry on the developer market are relatively small, and in many cases, the income from the sale of a flat in the city is sufficient to finance the purchase of a detached house in the surrounding towns. Katowice belongs to the large Silesian agglomeration where cities compete for inhabitants. Interestingly, we did not find any signs of asymmetry in the largest cities which also attract foreign capital and have significant income levels. According to Andre, Gupta and Mwamba (2019), the asymmetry and steepness behaviour of house prices is driven mainly by market factors. As mentioned in the Introduction, Poland is characterised by a shortage of housing in urban areas, especially in the largest and most rapidly developing cities. The above creates continuous demand for housing which did not decline even after the global financial crisis. Poland has been experiencing sustainable economic growth and a steady increase in wages since 2008. Only a minor increase in the unemployment rate was noted in the first years after the crisis, followed by a repeated decline.

Houses that were bought with a mortgage are also an important factor. In many countries, home buyers lost the means to repay their mortgages and were evicted, which drove down real estate prices. The Polish banking sector was prudent, and it offered mortgages to consumers with a high credit rating. Despite the difficulties faced by buyers who took out mortgages denominated in a foreign currency, the share of non-performing mortgages barely exceeded $3.5 \%$, a very low figure in comparison with other countries in the region.

Housing developers who influence the primary market as well as the secondary market through spillovers survived the crisis is surprisingly good form, did not have to resort to fire sales, and managed to keep the prices high. The prices on the secondary market tend to approximate those quoted on the primary market. In Poland, high prices on the primary market can be attributed to pre-sale contracts as well as developer strategies and their financial standing. The first and foremost factor are pre-sale contracts which entail some degree of risk for the buyer (developers rarely declare bankruptcy), but increase the elasticity of supply relative to the long-term construction process. The prepayments made by clients finance different stages of construction, which means that developers only use a small portion of their capital (see Augustyniak et al., 2012). According to Łaszek, Olszewski, et al. (2016), developers make additional profits by selling similar housing at different prices. This practice enables developers to maintain a high financial standing. Developers accumulated unsold housing stock in hope of making a profit in the future, especially that most of these resources were still under construction. 
Finally, the demand for housing was supported by subsidy programs, including "Family on its own" in 2007-2012 and "Housing for the young" in 2014-2018. Both programs were addressed to young first-time buyers and buyers who financed their purchase with mortgages denominated in PLN. The first program cut the interest rate by half for the first eight years to make mortgages more affordable. The second program increased down payments to improve the availability of mortgages. The subsidy depended on the number of children. The aim of both programs was to support less affluent households, and significant price limits were put in place. According to a report by the National Bank of Poland (2018a, pp. 27 and 28), the prices of subsidised housing during the market boom were below the average and median price, but they significantly exceeded the median and mean price in 2009 and 2010. According to a critical analysis by the NBP (2014, Box 1), subsidy programs failed to effectively target lower-income consumers and benefitted mainly middle-class buyers who had the means to purchase housing without subsidies.

The results of this study indicate that the Polish housing market experienced similar growth to other developed countries in Europe and the world, but a market downturn was slowed down and channelled into a slow recovery for three main reasons. Firstly, banks exercised caution and offered mortgages, including foreign currency mortgages, to the wealthier portion of the population. Secondly, the Polish economy and incomes continued to grow, which supported the repayment of mortgages despite foreign exchange shocks. Thirdly, the high performance of the developer sector coupled with subsidy programs maintained housing prices at a high level. As a result, the Polish real estate market emerged relatively unscathed from the global financial crisis relative to other countries. Significant tensions were not observed in the banking sector, and production levels remained high in the developer sector. The present cycle differs considerably from the "zero" cycle when many unexperienced developers had gone bankrupt, which ultimately led to first market cycle of 2004-2009 when house prices doubled.

\section{Appendix 1}

See Figs. 11, 12,13, 14 .
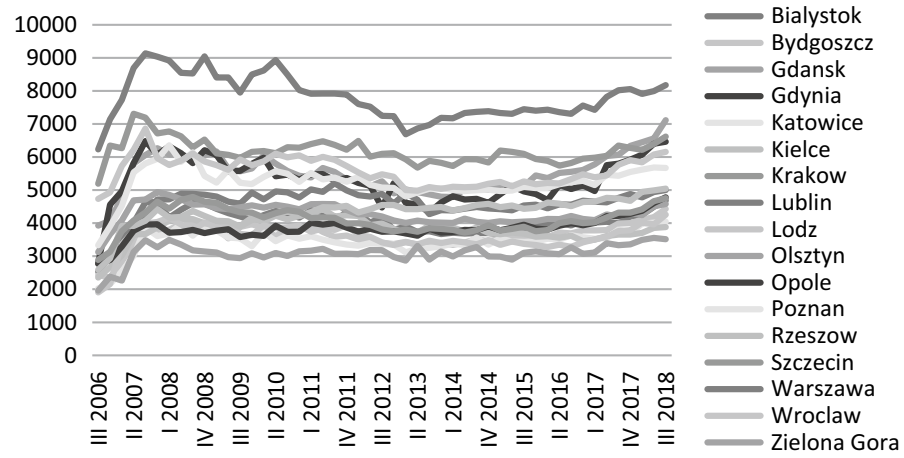

Fig. 11 Real prices-secondary market. Source: own elaboration 


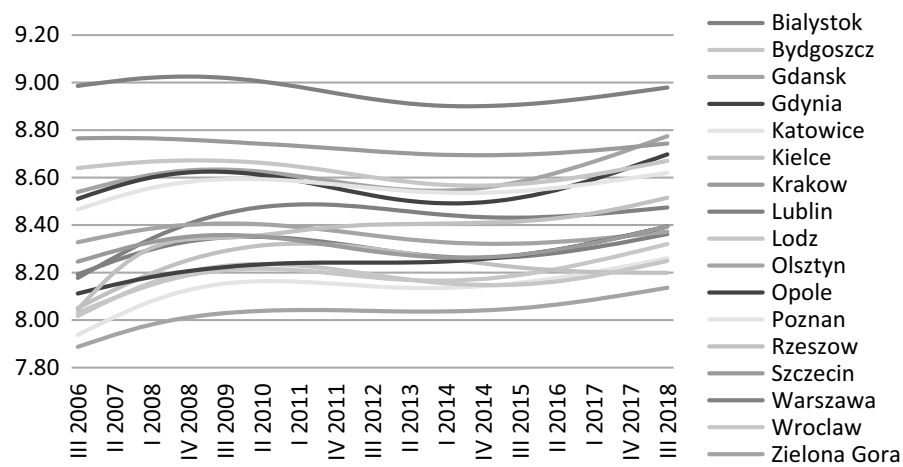

Fig. 12 Long-term trends, HP filter-secondary market. Natural logarithm. Source: own elaboration

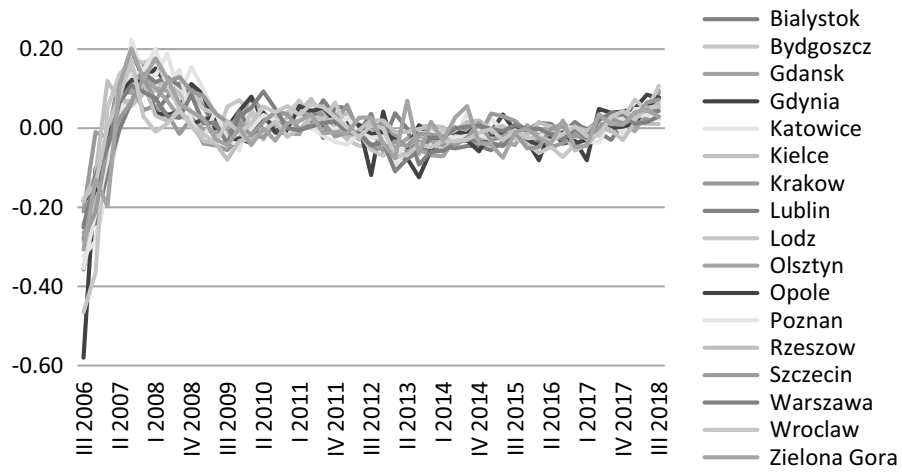

Fig. 13 Detrended data for analysing deepness asymmetry—secondary market. Source: own elaboration

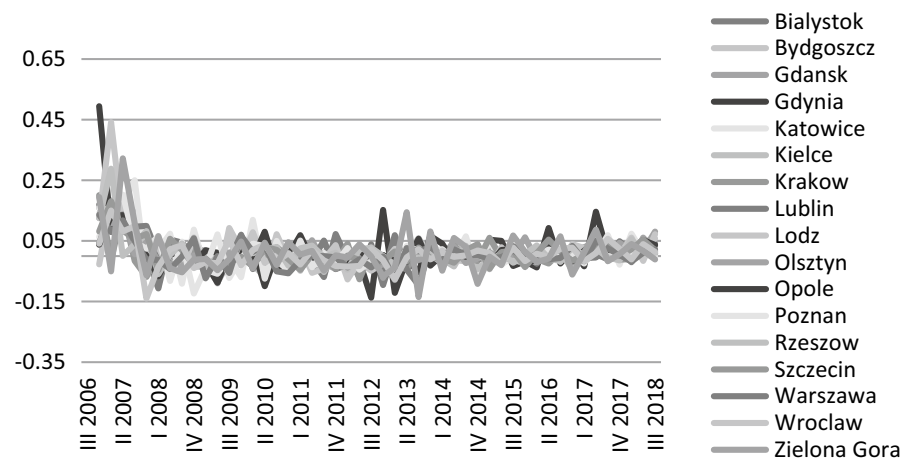

Fig. 14 First difference data for analysing steepness asymmetry-secondary market. Source: own elaboration 


\section{Appendix 2}

See Tables 3, 4, 5, and 6 .

Table 3 Descriptive statistics-primary market

\begin{tabular}{|c|c|c|c|c|c|c|c|c|c|}
\hline & $\mathrm{N}$ & Mean & Median & Minimum & Maximum & Interval & SD & $\mathrm{CV}$ & Skewness \\
\hline & \multicolumn{9}{|c|}{ Deepness } \\
\hline Bialystok & 49 & 0.000 & -0.001 & -0.264 & 0.154 & 0.417 & 0.078 & $1.07 \mathrm{E}+13$ & -1.153 \\
\hline Bydgoszcz & 49 & 0.000 & -0.003 & -0.272 & 0.167 & 0.439 & 0.082 & $1.21 \mathrm{E}+13$ & -1.196 \\
\hline Gdansk & 49 & 0.000 & -0.005 & -0.490 & 0.269 & 0.759 & 0.105 & $1.37 \mathrm{E}+13$ & -1.381 \\
\hline Gdynia & 49 & 0.000 & -0.004 & -0.306 & 0.194 & 0.499 & 0.088 & $1.05 \mathrm{E}+13$ & -0.448 \\
\hline Katowice & 49 & 0.000 & 0.005 & -0.243 & 0.185 & 0.428 & 0.090 & $9.83 \mathrm{E}+12$ & -0.236 \\
\hline Kielce & 49 & 0.000 & -0.004 & -0.229 & 0.200 & 0.429 & 0.077 & $8.75 E+12$ & -0.484 \\
\hline Krakow & 49 & 0.000 & 0.007 & -0.117 & 0.076 & 0.193 & 0.043 & $9.15 \mathrm{E}+12$ & -0.556 \\
\hline Lublin & 49 & 0.000 & -0.001 & -0.182 & 0.165 & 0.347 & 0.065 & $6.26 \mathrm{E}+12$ & 0.125 \\
\hline Lodz & 49 & 0.000 & -0.001 & -0.399 & 0.184 & 0.584 & 0.082 & $9.53 \mathrm{E}+12$ & -2.188 \\
\hline Olsztyn & 49 & 0.000 & -0.004 & -0.184 & 0.139 & 0.323 & 0.063 & $6.18 \mathrm{E}+12$ & -0.317 \\
\hline Opole & 49 & 0.000 & -0.006 & -0.138 & 0.182 & 0.320 & 0.069 & $9.37 \mathrm{E}+12$ & 0.470 \\
\hline Poznan & 49 & 0.000 & 0.000 & -0.441 & 0.215 & 0.656 & 0.094 & $1.11 \mathrm{E}+13$ & -1.838 \\
\hline Rzeszow & 49 & 0.000 & -0.007 & -0.240 & 0.167 & 0.407 & 0.064 & $1.01 \mathrm{E}+13$ & -0.512 \\
\hline Szczecin & 49 & 0.000 & -0.003 & -0.275 & 0.153 & 0.428 & 0.076 & $1.10 \mathrm{E}+13$ & -0.905 \\
\hline Warszawa & 49 & 0.000 & 0.001 & -0.249 & 0.130 & 0.379 & 0.064 & $8.89 \mathrm{E}+12$ & -1.198 \\
\hline Wroclaw & 49 & 0.000 & 0.004 & -0.389 & 0.368 & 0.757 & 0.095 & $8.68 \mathrm{E}+12$ & -0.459 \\
\hline \multirow[t]{2}{*}{ Zielona Gora } & 49 & 0.000 & 0.000 & -0.243 & 0.197 & 0.441 & 0.073 & $9.52 \mathrm{E}+12$ & -0.312 \\
\hline & \multicolumn{9}{|c|}{ Steepness } \\
\hline Bialystok & 48 & 0.012 & 0.005 & -0.051 & 0.234 & 0.285 & 0.048 & $3.97 \mathrm{E}+02$ & 2.379 \\
\hline Bydgoszcz & 48 & 0.015 & 0.008 & -0.078 & 0.305 & 0.383 & 0.059 & $4.03 \mathrm{E}+02$ & 2.487 \\
\hline Gdansk & 48 & 0.015 & 0.003 & -0.167 & 0.408 & 0.575 & 0.095 & $6.25 \mathrm{E}+02$ & 1.617 \\
\hline Gdynia & 48 & 0.011 & 0.007 & -0.102 & 0.187 & 0.289 & 0.062 & $5.84 \mathrm{E}+02$ & 0.628 \\
\hline Katowice & 48 & 0.009 & 0.009 & -0.188 & 0.291 & 0.479 & 0.088 & $9.53 \mathrm{E}+02$ & 0.067 \\
\hline Kielce & 48 & 0.011 & 0.003 & -0.133 & 0.457 & 0.590 & 0.077 & $7.05 \mathrm{E}+02$ & 4.055 \\
\hline Krakow & 48 & 0.000 & -0.001 & -0.080 & 0.088 & 0.168 & 0.033 & $1.09 \mathrm{E}+04$ & 0.146 \\
\hline Lublin & 48 & 0.012 & 0.006 & -0.100 & 0.163 & 0.264 & 0.054 & $4.33 \mathrm{E}+02$ & 0.355 \\
\hline Lodz & 48 & 0.013 & 0.007 & -0.155 & 0.250 & 0.405 & 0.066 & $5.07 \mathrm{E}+02$ & 1.673 \\
\hline Olsztyn & 48 & 0.015 & 0.008 & -0.070 & 0.143 & 0.213 & 0.047 & $3.23 \mathrm{E}+02$ & 0.841 \\
\hline Opole & 48 & 0.009 & 0.002 & -0.084 & 0.252 & 0.336 & 0.063 & $7.15 \mathrm{E}+02$ & 2.045 \\
\hline Poznan & 48 & 0.013 & 0.001 & -0.289 & 0.310 & 0.599 & 0.091 & $6.87 \mathrm{E}+02$ & 0.737 \\
\hline Rzeszow & 48 & 0.014 & 0.014 & -0.104 & 0.159 & 0.264 & 0.056 & $3.86 \mathrm{E}+02$ & 0.439 \\
\hline Szczecin & 48 & 0.012 & 0.003 & -0.090 & 0.253 & 0.343 & 0.059 & $4.99 \mathrm{E}+02$ & 1.613 \\
\hline Warszawa & 48 & 0.009 & 0.008 & -0.077 & 0.166 & 0.243 & 0.044 & $5.00 \mathrm{E}+02$ & 1.002 \\
\hline Wroclaw & 48 & 0.015 & 0.011 & -0.289 & 0.626 & 0.915 & 0.110 & $7.12 \mathrm{E}+02$ & 3.309 \\
\hline Zielona Gora & 48 & 0.009 & 0.003 & -0.102 & 0.265 & 0.367 & 0.058 & $6.24 \mathrm{E}+02$ & 2.552 \\
\hline
\end{tabular}

Source: own elaboration 
Table 4 Descriptive statistics—-secondary market

\begin{tabular}{|c|c|c|c|c|c|c|c|c|c|}
\hline & $\mathrm{N}$ & Mean & Median & Minimum & Maximum & Interval & SD & $\mathrm{CV}$ & Skewness \\
\hline \multicolumn{10}{|l|}{ Deepness } \\
\hline Bialystok & 49 & 0.000 & -0.005 & -0.357 & 0.174 & 0.532 & 0.081 & $9.49 \mathrm{E}+12$ & -1.684 \\
\hline Bydgoszcz & 49 & 0.000 & -0.005 & -0.286 & 0.159 & 0.445 & 0.077 & $1.91 \mathrm{E}+13$ & -1.318 \\
\hline Gdansk & 49 & 0.000 & -0.004 & -0.264 & 0.141 & 0.405 & 0.075 & $1.22 \mathrm{E}+13$ & -1.278 \\
\hline Gdynia & 49 & 0.000 & 0.004 & -0.580 & 0.201 & 0.781 & 0.109 & $1.71 \mathrm{E}+13$ & -3.025 \\
\hline Katowice & 49 & 0.000 & -0.011 & -0.323 & 0.224 & 0.547 & 0.093 & $1.43 \mathrm{E}+13$ & -0.901 \\
\hline Kielce & 49 & 0.000 & 0.004 & -0.287 & 0.116 & 0.403 & 0.068 & $1.39 \mathrm{E}+13$ & -1.800 \\
\hline Krakow & 49 & 0.000 & -0.006 & -0.211 & 0.130 & 0.340 & 0.050 & $7.07 \mathrm{E}+12$ & -0.984 \\
\hline Lublin & 49 & 0.000 & 0.000 & -0.251 & 0.140 & 0.392 & 0.073 & $1.14 \mathrm{E}+13$ & -1.313 \\
\hline Lodz & 49 & 0.000 & -0.004 & -0.465 & 0.175 & 0.641 & 0.107 & $1.21 \mathrm{E}+13$ & -2.289 \\
\hline Olsztyn & 49 & 0.000 & -0.003 & -0.280 & 0.127 & 0.407 & 0.059 & $5.97 \mathrm{E}+12$ & -1.983 \\
\hline Opole & 49 & 0.000 & -0.009 & -0.183 & 0.123 & 0.306 & 0.053 & $5.99 \mathrm{E}+12$ & -0.768 \\
\hline Poznan & 49 & 0.000 & -0.005 & -0.355 & 0.201 & 0.556 & 0.083 & $1.76 \mathrm{E}+13$ & -1.373 \\
\hline Rzeszow & 49 & 0.000 & 0.001 & -0.185 & 0.119 & 0.305 & 0.047 & $-2.70 E+14$ & -0.909 \\
\hline Szczecin & 49 & 0.000 & -0.001 & -0.278 & 0.130 & 0.408 & 0.070 & $7.74 \mathrm{E}+12$ & -1.493 \\
\hline Warszawa & 49 & 0.000 & 0.004 & -0.249 & 0.108 & 0.357 & 0.059 & $6.03 E+12$ & -1.571 \\
\hline Wroclaw & 49 & 0.000 & 0.000 & -0.177 & 0.173 & 0.351 & 0.054 & $4.31 \mathrm{E}+12$ & -0.340 \\
\hline Zielona Gora & 49 & 0.000 & 0.001 & -0.307 & 0.202 & 0.509 & 0.082 & $2.15 \mathrm{E}+13$ & -0.799 \\
\hline \multicolumn{10}{|l|}{ Steepness } \\
\hline Bialystok & 48 & 0.013 & 0.005 & -0.107 & 0.180 & 0.287 & 0.057 & $4.45 \mathrm{E}+02$ & 0.900 \\
\hline Bydgoszcz & 48 & 0.013 & 0.003 & -0.090 & 0.188 & 0.279 & 0.053 & $4.24 \mathrm{E}+02$ & 1.545 \\
\hline Gdansk & 48 & 0.012 & 0.006 & -0.087 & 0.193 & 0.280 & 0.049 & $3.96 \mathrm{E}+02$ & 1.424 \\
\hline Gdynia & 48 & 0.018 & 0.006 & -0.137 & 0.494 & 0.631 & 0.095 & $5.40 \mathrm{E}+02$ & 2.748 \\
\hline Katowice & 48 & 0.014 & 0.005 & -0.091 & 0.250 & 0.341 & 0.067 & $4.63 \mathrm{E}+02$ & 1.301 \\
\hline Kielce & 48 & 0.010 & 0.004 & -0.068 & 0.192 & 0.260 & 0.047 & $4.53 \mathrm{E}+02$ & 1.647 \\
\hline Krakow & 48 & 0.005 & -0.004 & -0.077 & 0.201 & 0.278 & 0.047 & $9.34 \mathrm{E}+02$ & 1.989 \\
\hline Lublin & 48 & 0.012 & 0.000 & -0.096 & 0.157 & 0.253 & 0.047 & $3.86 \mathrm{E}+02$ & 0.872 \\
\hline Lodz & 48 & 0.017 & 0.007 & -0.077 & 0.442 & 0.519 & 0.076 & $4.53 \mathrm{E}+02$ & 3.888 \\
\hline Olsztyn & 48 & 0.008 & -0.001 & -0.040 & 0.159 & 0.199 & 0.040 & $5.03 \mathrm{E}+02$ & 2.217 \\
\hline Opole & 48 & 0.011 & 0.011 & -0.067 & 0.135 & 0.202 & 0.041 & $3.62 \mathrm{E}+02$ & 0.918 \\
\hline Poznan & 48 & 0.011 & 0.004 & -0.123 & 0.203 & 0.326 & 0.056 & $5.07 \mathrm{E}+02$ & 1.078 \\
\hline Rzeszow & 48 & 0.014 & 0.008 & -0.059 & 0.288 & 0.348 & 0.052 & $3.75 \mathrm{E}+02$ & 3.337 \\
\hline Szczecin & 48 & 0.010 & 0.005 & -0.046 & 0.181 & 0.227 & 0.042 & $4.07 \mathrm{E}+02$ & 1.501 \\
\hline Warszawa & 48 & 0.006 & 0.000 & -0.079 & 0.136 & 0.216 & 0.042 & $7.45 \mathrm{E}+02$ & 0.771 \\
\hline Wroclaw & 48 & 0.005 & 0.009 & -0.140 & 0.150 & 0.290 & 0.044 & $8.09 \mathrm{E}+02$ & 0.140 \\
\hline Zielona Gora & 48 & 0.012 & -0.001 & -0.135 & 0.322 & 0.458 & 0.076 & $6.21 \mathrm{E}+02$ & 1.705 \\
\hline
\end{tabular}

Source: own elaboration 
Table 5 Results of the Shapiro-Wilk test—primary market

\begin{tabular}{|c|c|c|}
\hline & \multicolumn{2}{|l|}{ Primary market } \\
\hline & Deepness & Steepness \\
\hline & S-W Test & S-W Test \\
\hline Bialystok & $\mathrm{W}=.85774 . p=.00003$ & $\mathrm{~W}=.81053 \cdot p=.00000$ \\
\hline Bydgoszcz & $\mathrm{W}=.86519 \cdot p=.00005$ & $\mathrm{~W}=.80827 \cdot p=.00000$ \\
\hline Gdansk & $\mathrm{W}=.76100 . p=.00000$ & $\mathrm{~W}=.86426 . p=.00005$ \\
\hline Gdynia & $\mathrm{W}=.9575 \cdot p=.07504 * *$ & $\mathrm{~W}=.95536 . p=.0655^{* *} *$ \\
\hline Katowice & $\mathrm{W}=.95619 \cdot p=.06604 * *$ & $\mathrm{~W}=.94065 . p=.0172 * * *$ \\
\hline Kielce & $\mathrm{W}=.88910 . p=.00025$ & $\mathrm{~W}=.62406 . p=.00000$ \\
\hline Krakow & $\mathrm{W}=.96609 \cdot p=.16842 * *$ & $\mathrm{~W}=.98828 . p=.90914 * *$ \\
\hline Lublin & $\mathrm{W}=.91945 \cdot p=.00253$ & $\mathrm{~W}=.97526 . p=.39965^{* *}$ \\
\hline Lodz & $\mathrm{W}=.77937 \cdot p=.00000$ & $\mathrm{~W}=.80942 . p=.00000$ \\
\hline Olsztyn & $\mathrm{W}=.96262 . p=.12143^{*} *$ & $\mathrm{~W}=.94163 \cdot p=.01875^{*} * *$ \\
\hline Opole & $\mathrm{W}=.97717 . p=.45318 * *$ & $\mathrm{~W}=.81372 . p=.00000$ \\
\hline Poznan & $\mathrm{W}=.77516 \cdot p=.00000$ & $\mathrm{~W}=.81539 \cdot p=.00000$ \\
\hline Rzeszow & $\mathrm{W}=.90143 \cdot p=.00061$ & $\mathrm{~W}=.98018 \cdot p=.58602 * *$ \\
\hline Szczecin & $\mathrm{W}=.89933 \cdot p=.00052$ & $\mathrm{~W}=.88994 . p=.00030$ \\
\hline Warszawa & $\mathrm{W}=.87721 \cdot p=.00011$ & $\mathrm{~W}=.93911 . p=.01500^{* * *}$ \\
\hline Wroclaw & $\mathrm{W}=.74255 \cdot p=.00000$ & $\mathrm{~W}=.61298 . p=.00000$ \\
\hline Zielona Gora & $\mathrm{W}=.77974 \cdot p=.00000$ & $\mathrm{~W}=.69447 \cdot p=.00000$ \\
\hline
\end{tabular}

${ }^{*}$ Significant at $0.1 ; * *$ significant at $0.05 ; * * *$ significant at 0.01

Source: own elaboration 
Table 6 Results of the ShapiroWilk test—secondary market

\begin{tabular}{|c|c|c|}
\hline & \multicolumn{2}{|l|}{ Secondary market } \\
\hline & Deepness & Steepness \\
\hline & Test S-W & Test S-W \\
\hline Bialystok & $\mathrm{W}=.83906 . p=.00001$ & $\mathrm{~W}=.92598 . p=.00486$ \\
\hline Bydgoszcz & $\mathrm{W}=.88121 . p=.00014$ & $\mathrm{~W}=.86592 . p=.00006$ \\
\hline Gdansk & $\mathrm{W}=.88579 . p=.00019$ & $\mathrm{~W}=.89442 . p=.00042$ \\
\hline Gdynia & $\mathrm{W}=.74953 . p=.00000$ & $\mathrm{~W}=.77817 \cdot p=.00000$ \\
\hline Katowice & $\mathrm{W}=.86476 . p=.00005$ & $\mathrm{~W}=.91135 . p=.00149$ \\
\hline Kielce & $\mathrm{W}=.86148 . p=.00004$ & $\mathrm{~W}=.87631 . p=.00012$ \\
\hline Krakow & $\mathrm{W}=.87570 . p=.00010$ & $\mathrm{~W}=.82482 . p=.00000$ \\
\hline Lublin & $\mathrm{W}=.88092 . p=.00014$ & $\mathrm{~W}=.94268 \cdot p=.02060^{* * *}$ \\
\hline Lodz & $\mathrm{W}=.76122 . p=.00000$ & $\mathrm{~W}=.65460 . p=.00000$ \\
\hline Olsztyn & $\mathrm{W}=.79515 . p=.00000$ & $\mathrm{~W}=.77740 . p=.00000$ \\
\hline Opole & $\mathrm{W}=.90016 \cdot p=.00056$ & $\mathrm{~W}=.93885 \cdot p=.01467^{* * *}$ \\
\hline Poznan & $\mathrm{W}=.79436 \cdot p=.00000$ & $\mathrm{~W}=.90097 \cdot p=.00068$ \\
\hline Rzeszow & $\mathrm{W}=.85284 \cdot p=.00002$ & $\mathrm{~W}=.70725 . p=.00000$ \\
\hline Szczecin & $\mathrm{W}=.84543 . p=.00001$ & $\mathrm{~W}=.89715 . p=.00051$ \\
\hline Warszawa & $\mathrm{W}=.88107 \cdot p=.00014$ & $\mathrm{~W}=.94082 \cdot p=.01745^{* * *}$ \\
\hline Wroclaw & $\mathrm{W}=.92113 . p=.00291$ & $\mathrm{~W}=.92932 . p=.00644$ \\
\hline Zielona Gora & $\mathrm{W}=.90580 \cdot p=.00085$ & $\mathrm{~W}=.88047 \cdot p=.00016$ \\
\hline
\end{tabular}

* significant at $0.1 ; * *$ significant at $0.05 ; * * *$ significant at 0.01

Source: own elaboration

Open Access This article is licensed under a Creative Commons Attribution 4.0 International License, which permits use, sharing, adaptation, distribution and reproduction in any medium or format, as long as you give appropriate credit to the original author(s) and the source, provide a link to the Creative Commons licence, and indicate if changes were made. The images or other third party material in this article are included in the article's Creative Commons licence, unless indicated otherwise in a credit line to the material. If material is not included in the article's Creative Commons licence and your intended use is not permitted by statutory regulation or exceeds the permitted use, you will need to obtain permission directly from the copyright holder. To view a copy of this licence, visit http://creativecommons.org/licenses/by/4.0/.

\section{References}

André, C. (2010). A bird's eye view of OECD housing markets. OECD Economics Department Working Papers, No. 746, OECD Publishing.

André, C., Gupta, R., \& Mwamba, J. W. M. (2019). Are housing price cycles asymmetric? Evidence from the US States and Metropolitan areas. International Journal of Strategic Property Management, 23(1), 1-22.

Anundsen, A. K., Gerdrup, K., Hansen, F., \& Kragh-Sørensen, K. (2016). Bubbles and crises: The role of house prices and credit. Journal of Applied Econometrics, 31(7), 1291-1311.

Aoki, K., Proudman, J., \& Vlieghe, G. (2004). House prices, consumption, and monetary policy: A financial accelerator approach. Journal of Financial Intermediation, 13(4), 414-435.

Augustyniak, H., Gajewski, K., Łaszek, J., \& Żochowski, G. (2012). Real estate development enterprises in the Polish market and issues related to its analysis. MPRA Paper No. 43347. 
Balk, B., Diewert, Walter Erwin Fenwick, D., Prud'homme, M., \& de Haan, J. (2013). Handbook on residential property prices (RPPIs). In Handbook on Residential Property Prices (RPPIs). https://doi.org/ $10.5089 / 9789279259845.069$

Batóg, B., \& Foryś, I. (2010). Modele logitowe w analizie transakcji na warszawskim rynku mieszkaniowym. Studia i Materiaty TNN, 19(2), 34-48.

Belaire-Franch, J., \& Contreras, D. (2003). An assessment of international business cycle asymmetries using Clements and Krolzig's parametric approach. Studies in Nonlinear Dynamics \& Econometrics, $6(4), 1-9$.

Bełej, M. (2012). Dynamika zmian cen nieruchomości w aspekcie teorii przejść nieciągłych. Studia $i$ Materiały Towarzystwa Naukowego Nieruchomości, 20(1), 17-28.

Bełej, M., \& Kulesza, S. (2011). Modelowanie cen na rynku nieruchomości w warunkach nieciągłości. Wycena, 3(96), 15-19.

Bełej, M., \& Kulesza, S. (2013). Real estate market under catastrophic change. Acta Physica Polonica a., 123(3), 497-501.

Bełej, M. (2018). Synergistic network connectivity among urban areas based on non-linear model of housing prices dynamics. Real Estate Management and Valuation, 26(4), 22-34.

Bernanke, B. S., Gertler, M., \& Gilchrist, S. (1999). The financial accelerator in a quantitative business cycle framework. Handbook of Macroeconomics, 1, 1341-1393.

Brown, G. R., \& Matysiak, G. A. (2000). Sticky valuations, aggregation effects, and property indices. The Journal of Real Estate Finance and Economics, 20(1), 49-66.

Brunnermeier, M. K. (2009). Deciphering the liquidity and credit crunch 2007-2008. Journal of Economic Perspectives, 23(1), 77-100.

Brzezicka, J., Wisniewski, R., \& Figurska, M. (2018). Disequilibrium in the real estate market: Evidence from Poland. Land Use Policy, 78, 515-531.

Brzezicka, J., Łaszek, J., Olszewski, K., \& Waszczuk, J. (2019). Analysis of the filtering process and the ripple effect on the primary and secondary housing market in Warsaw, Poland. Land Use Policy, 88, 104098.

Capozza, D.R., Hendershott, P.H., Mack, C., \& Mayer, C.J. (2002). Determinants of real house price dynamics. National Bureau of Economic Research. Working paper Nr. 9262.

Chen, W. D. (2016). Policy failure or success? Detecting market failure in China's housing market. Economic Modelling, 56, 109-121.

Cook, S. (2006). A disaggregated analysis of asymmetrical behaviour in the UK housing market. Urban Studies, 43(11), 2067-2207.

Czerski, J., Gluszak, M., \& Zygmunt, R. W. (2017). Repeat sales index for residential real estate in Krakow. Institute of Economic Research Working Papers, Institute of Economic Research (IER), Toruń, 29.

European Central Bank (2005). Asset price bubbles and monetary policy. In: Monthly Bulletin. European Central Bank.

DiPasquale, D., \& Wheaton, W. C. (1992). The markets for real estate assets and space: A conceptual framework. Real Estate Economics, 20(2), 181-198.

Feng, Q., \& Wu, G. L. (2015). Bubble or riddle? An asset-pricing approach evaluation on China's housing market. Economic Modelling, 46, 376-383.

Foryś, I. (2009). Wykorzystanie analizy wielowymiarowej do oceny potencjału rozwoju lokalnego rynku nieruchomości mieszkaniowych. Studia i Materiaty Towarzystwa Naukowego Nieruchomości, 17(2), $7-19$.

Foryś, I. (2013a). Stabilność wybranych prawidłowości opisujących obrót mieszkaniami w wybranym segmencie na przykładzie szczecińskiego rynku. Studia i Prace Wydziału Nauk Ekonomicznych i Zarzqdzania, $31,135-144$.

Foryś, I. (2013b). Wykorzystanie indeksów cen mieszkań do oceny zwrotu z inwestycji bezpośrednich na przykładzie wybranego rynku lokalnego. Zeszyty Naukowe Uniwersytetu Szczecińskiego. Finanse, Rynki Finansowe, Ubezpieczenia, 63, 109-126.

Gallin, J. (2006). The long-run relationship between house prices and income: Evidence from local housing markets. Real Estate Economics, 34(3), 417-438.

Geltner, D. (2015). Real estate price indices and price dynamics: An overview from an investments perspective. Annual Review of Financial Economics, 7, 615-633.

Gdakowicz, A., \& Hozer, J. (2012). Analiza rozwoju rynków nieruchomości mieszkaniowych w wybranych miastach Polski z zastosowaniem metod taksonomicznych. Studia i Materiaty Towarzystwa Naukowego Nieruchomości, 20(1), 123-133.

Girouard, N., M. Kennedy, P. Van den Noord, \& André C., 2006, Recent House Price Developments: the Role of Fundamentals, OECD Economics Department Working Papers, No. 475, OECD, Paris. 
Głuszak, M., Czerski, J., \& Zygmunt, R. (2018). Estimating repeat sales residential price indices for Krakow. Oeconomia Copernicana, 9(1), 55-69. https://doi.org/10.24136/oc.2018.003

Hamilton, J. D. (2018). Why you should never use the Hodrick-Prescott filter. Review of Economics and Statistics, $100(5), 831-843$.

Helbling, T. F. (2005). Housing price bubbles-a tale based on housing price booms and busts. BIS Papers, 21, $30-41$.

Herring, R. J., \& Wachter, S. M. (1999). Real estate booms and banking busts: An international perspective. The Wharton School Research Paper (99-27).

Hill, R., \& Trojanek, R. (2020). House Price Indexes for Warsaw: An Evaluation of Competing Methods. Graz Economics Papers, University of Graz, Department of Economics, 2020-08(March).

Hott, C. (2009) Explaining house price fluctuations. Working Papers 2009-05, Swiss National Bank.

Iacoviello, M., \& Neri, S. (2010). Housing market spillovers: evidence from an estimated DSGE model. American Economic Journal: Macroeconomics, 2(2), 125-164.

Iacoviello, M. (2015). Financial business cycles. Review of Economic Dynamics, 18(1), 140-163.

Jordá, Ò., Schularick, M., \& Taylor, A. (2014). The great mortgaging: housing finance, crises, and business cycles. National Bureau of Economic Research. Working Paper No. 20501.

Kim, J., \& Lim, R. G. (2016). Fundamentals and rational bubbles in the Korean housing market: A modified present-value approach. Economic Modelling, 59, 174-181.

Kulesza, S., \& Bełej, M. (2015). Local real estate markets in Poland as a network of damped harmonic oscillators. Acta Physica Polonica A, 127(3-A), 99-102.

Lambertini, L., Mendicino, C., \& Punzi, M. T. (2017). Expectations-driven cycles in the housing market. Economic Modelling, 60, 297-312.

Leamer, E. E. (2007). Housing is the business cycle. National Bureau of Economic Research. Working paper nr. 13428.

Leamer, E. E. (2015). Housing really is the business cycle: What survives the lessons of 2008-09? Journal of Money, Credit and Banking, 47(S1), 43-50.

Lee, J., \& Song, J. (2015). Housing and business cycles in Korea: A multi-sector Bayesian DSGE approach. Economic Modelling, 45, 99-108.

Leszczyński, R., \& Olszewski, K. (2017). An analysis of the primary and secondary housing market in Poland: Evidence from the 17 largest cities. Baltic Journal of Economics, 17(2), 136-151.

Leung, C. K. Y., \& Wang, W. (2007). An examination of the Chinese housing market through the lens of the DiPasquale-Wheaton model: A graphical attempt. International Real Estate Review, 10(2), 131-165.

Łaszek, J., Augustyniak, H., \& Olszewski, K. (2016a). FX mortgages, housing boom and financial stability-a case study for Poland (2005-2015). The Narodowy Bank Polski Workshop: Recent Trends in the Real Estate Market and Its Analysis - 2015 Edition.

Łaszek, J., Olszewski, K., \& Waszczuk, J. (2016). Monopolistic Competition and Price Discrimination as a Development Company Strategy in the Primary Housing Market. Critical Housing Analysis, 3(2), 1-12.

Łaszek, J., Olszewski, K., \& Augustyniak, H. (2018). A simple model of the housing market and the detection of cycles. In J. Łaszek, K. Olszewski, \& R. Sobiecki (Eds.), Recent trends in the real estate market and its analysis. Warsaw: Oficyna Wydawnicza SGH.

Malpezzi, S. (1999). A simple error correction model of house prices. Journal of Housing Economics, 8(1), 27-62.

Malpezzi, S., \& Wachter, S. (2005). The role of speculation in real estate cycles. Journal of Real Estate Literature, $13(2), 141-164$.

NBP. (2014) Report on the situation in the Polish residential real estate market in 2013. Narodowy Bank Polski.

NBP (2018a) Information on home prices and the situation in the housing and commercial real estate market in Poland in 2017 Q4. Narodowy Bank Polski.

NBP (2018b) Report on the situation in the Polish residential real estate market in 2017. Narodowy Bank Polski. https://www.nbp.pl/homen.aspx?f=/en/publikacje/inne/real_estate_market_q.html.

Olszewski, K., Waszczuk, J., \& Widłak, M. (2017). Spatial and hedonic analysis of house price dynamics in Warsaw, Poland. Journal of Urban Planning and Development, 143(3), 04017009.

Quan, D. C., \& Quigley, J. M. (1991). Price formation and the appraisal function in real estate markets. The Journal of Real Estate Finance and Economics, 4(2), 127-146.

Racine, J., \& Maasoumi, E. (2008). A robust entropy-based test of asymmetry for discrete and continuous processes. Econometric Reviews, 28, 246-261.

Randles, R. H., Fligner, M. A., Policello, G. E., \& Wolfe, D. A. (1980). An asymptotically distribution-free test for symmetry versus asymmetry. Journal of the American Statistical Association, 75(369), 168-172.

Razzak, W. A. (2001). Business cycle asymmetries: International evidence. Review of Economic Dynamics, $4(1), 230-243$. 
Reinhart, C. M., \& Rogoff, K. S. (2009). This time is different, eight centuries of financial folly. Princeton University Press.

Roubini, N. (2006). Why central banks should burst bubbles. International Finance, 9(1), 87-107.

Shi, S. (2017). Speculative bubbles or market fundamentals? An investigation of US regional housing markets. Economic Modelling, 66, 101-111.

Trojanek, R. (2009). Porównanie metody średniej oraz średniej ważonej konstruowania indeksów cen nieruchomości mieszkaniowych. Studia i Materiaty Towarzystwa Naukowego Nieruchomosci, 17(2), $31-43$.

Trojanek, R. (2011). House price cycles-the case of Poland. Journal of International Studies, 4(1), 9-17.

Trojanek, R. (2012). An analysis of changes in dwelling prices in the biggest cities of Poland in 2008-2012 conducted with the application of the hedonic method. Actual Problems of Economics, 7(2), 5-14.

Trojanek, R. (2018). Teoretyczne i metodyczne aspekty wyznaczania indeksów cen na rynku mieszkaniowym. [Theoretical and methodological aspects of determining price indices in the housing market]. Wydawnictwo Uniwersytetu Ekonomicznego w Poznaniu, Poznań.

Trzęsiok, M. (2013). Wycena rynkowej wartości nieruchomości z wykorzystaniem wybranych metod wielowymiarowej analizy statystycznej. Research Papers of the Wroclaw University of Economics/prace Naukowe Uniwersytetu Ekonomicznego We Wroclawiu, 278, 188-196.

Tyc, W. (2013). Modele Idealizacyjne Baniek Cenowych. Przeglad Zachodniopomorski, 3(1), 339-356.

Widłak, M., \& Tomczyk, E. (2010). Measuring price dynamics: evidence from the Warsaw housing market. Journal of European Real Estate Research, 3(3), 203-227.

Wiśniewski, R. (2008). Efficient real estate market in Poland. Poznan University of Economics Review, 8(1), 55-77.

Verbrugge, R. (1997). Investigating cyclical asymmetries. Studies in Nonlinear Dynamics \& Econometrics, 2(1), 15-22.

Verbrugge, R. (1998). A cross-country investigation of macroeconomic asymmetries. Economic Working Paper Archive, Macroeconomics, No. 9809017.

Yilanci, V. (2012). Investigating asymmetries in macroeconomic aggregates of central and Eastern European economies. Amfiteatru Economic, 14(31), 223-229.

Publisher's Note Springer Nature remains neutral with regard to jurisdictional claims in published maps and institutional affiliations. 